\title{
Development and testing scenarios for implementing land use and land cover changes during the Holocene in Earth system model experiments
}

\author{
Sandy P. Harrison ${ }^{1}$, Marie-José Gaillard ${ }^{2}$, Benjamin D. Stocker ${ }^{3,4}$, Marc Vander Linden ${ }^{5}$, Kees Klein Goldewijk ${ }^{6,7}$, \\ Oliver Boles $^{8}$, Pascale Braconnot ${ }^{9}$, Andria Dawson ${ }^{10}$, Etienne Fluet-Chouinard ${ }^{11}$, Jed O. Kaplan ${ }^{12,13}$, \\ Thomas Kastner ${ }^{14}$, Francesco S. R. Pausata ${ }^{15}$, Erick Robinson ${ }^{16}$, Nicki J. Whitehouse ${ }^{17}$, Marco Madella ${ }^{18,19,20}$, and \\ Kathleen D. Morrison ${ }^{8}$ \\ ${ }^{1}$ Department of Geography and Environmental Science, University of Reading, Reading, UK \\ ${ }^{2}$ Department of Biology and Environmental Science, Linnaeus University, Kalmar, Sweden \\ ${ }^{3}$ Ecological and Forestry Applications Research Centre, Cerdanyola del Vallès, Spain \\ ${ }^{4}$ Department of Earth System Science, Stanford University, Stanford, CA 94305, USA \\ ${ }^{5}$ Department of Archaeology, University of Cambridge, Cambridge, UK \\ ${ }^{6}$ PBL Netherlands Environmental Assessment Agency, the Hague, the Netherlands \\ ${ }^{7}$ Copernicus Institute of Sustainable Development, Utrecht University, Utrecht, the Netherlands \\ ${ }^{8}$ University Museum of Archaeology \& Anthropology, University of Pennsylvania, Philadelphia, USA \\ ${ }^{9}$ Laboratoire des Sciences du Climat et de l'Environnement, Gif-sur-Yvette, France \\ ${ }^{10}$ Department of General Education, Mount Royal University, Calgary, Canada \\ ${ }^{11}$ Department of Earth System Science, Stanford University, Stanford, California, USA \\ ${ }^{12}$ Department of Earth Sciences, University of Hong Kong, Hong Kong \\ ${ }^{13}$ Institute of Geography, University of Augsburg, Augsburg, Germany \\ ${ }^{14}$ Senckenberg Biodiversity and Climate Research Centre, Frankfurt am Main, Germany \\ ${ }^{15}$ Centre ESCER, Department of Earth and Atmospheric Sciences, University of Quebec in Montreal, Montreal, Canada \\ ${ }^{16}$ Department of Anthropology, University of Wyoming, Laramie, Wyoming, USA \\ ${ }^{17}$ School of Geography, Earth and Environmental Science, University of Plymouth, Plymouth, UK \\ ${ }^{18}$ Department of Humanities (CaSEs), University Pompeu Fabra, Barcelona, Spain \\ ${ }^{19}$ ICREA Passeig Lluís Companys 23, 08010 Barcelona, Spain \\ ${ }^{20}$ School of Geography, Archaeology and Environmental Studies, University of the Witwatersrand, \\ Johannesburg, South Africa
}

Correspondence: Sandy P. Harrison (s.p.harrison@reading.ac.uk)

Received: 5 May 2019 - Discussion started: 23 July 2019

Revised: 12 January 2020 - Accepted: 20 January 2020 - Published: 2 March 2020

\begin{abstract}
Anthropogenic changes in land use and land cover (LULC) during the pre-industrial Holocene could have affected regional and global climate. Existing scenarios of LULC changes during the Holocene are based on relatively simple assumptions and highly uncertain estimates of population changes through time. Archaeological and palaeoenvironmental reconstructions have the potential to refine these assumptions and estimates. The Past Global
\end{abstract}

Changes (PAGES) LandCover6k initiative is working towards improved reconstructions of LULC globally. In this paper, we document the types of archaeological data that are being collated and how they will be used to improve LULC reconstructions. Given the large methodological uncertainties involved, both in reconstructing LULC from the archaeological data and in implementing these reconstructions into global scenarios of LULC, we propose a protocol to evaluate 
the revised scenarios using independent pollen-based reconstructions of land cover and climate. Further evaluation of the revised scenarios involves carbon cycle model simulations to determine whether the LULC reconstructions are consistent with constraints provided by ice core records of $\mathrm{CO}_{2}$ evolution and modern-day LULC. Finally, the protocol outlines how the improved LULC reconstructions will be used in palaeoclimate simulations in the Palaeoclimate Modelling Intercomparison Project to quantify the magnitude of anthropogenic impacts on climate through time and ultimately to improve the realism of Holocene climate simulations.

\section{Introduction and motivation}

Today, ca. $10 \%$ of the ice-free land surface is estimated to be intensively managed, and much of the reminder is under less intense anthropogenic use or influenced by human activities (Arneth et al., 2019). Substantial transformations of natural ecosystems by humans began with the geographically diachronous shift from hunting and gathering characteristic of the Mesolithic to cultivation and more permanent settlement during the Neolithic period (Mazoyer and Roudart, 2006; Zohary et al., 2012; Tauger, 2013; Maezumi et al., 2018), although there is controversy about the relative importance of climate changes and human impact on landscape development both during and since that time. Resolving the uncertainty about the extent and timing of land use is important because changes in land cover as a result of land use (land use land cover: LULC) have the potential to impact climate and the carbon cycle. Direct climate impacts occur through changes in the surface energy budget resulting from modifications of surface albedo, evapotranspiration, and canopy structure (biophysical impacts; e.g. Pongratz et al., 2010; Myhre et al., 2013; Perugini et al., 2017). LULC affects the carbon cycle through modifications in vegetation, soil carbon storage (biogeochemical impacts; e.g. Pongratz et al., 2010; Mahowald et al., 2017), and turnover times, which change the $\mathrm{C}$ sink and source capacity of the terrestrial biosphere. LULC changes have substantially contributed to the increase in atmospheric greenhouse gases during the industrial period (Le Quéré et al., 2018). It has been suggested that greenhouse gas emissions associated with Neolithic LULC changes were sufficiently large to offset climate cooling after the mid-Holocene (the overdue glaciation hypothesis: Ruddiman, 2003). Although this has been challenged for several reasons, including inconsistency with the land carbon balance derived from ice core and peat records (e.g. Joos et al., 2004; Kaplan et al., 2011; Singarayer et al., 2011; Mitchell et al., 2013; Stocker et al., 2017), an LULC impact on climate in more recent millennia appears more plausible.

Climate model simulations have shown that LULC changes have discernible impacts on climate, both in regions with large prescribed changes in LULC and in teleconnected regions with no major local human activity (Vavrus et al., 2008; Pongratz et al., 2010; He et al., 2014; Smith et al., 2016). At the global scale, the biogeophysical effects of the accumulated LULC change during the Holocene, which resulted in reconstructed land cover patterns in $1850 \mathrm{CE}$, have been estimated to cause a slight cooling $\left(0.17^{\circ} \mathrm{C}\right)$ that is offset by biogeochemical warming $\left(0.9^{\circ} \mathrm{C}\right)$, giving a net global warming $\left(0.73^{\circ} \mathrm{C}\right)(\mathrm{He}$ et al., 2014). However, in these simulations, biophysical and biogeochemical effects were of comparable magnitude in the most intensively altered landscapes of Europe, Asia, and North America (He et al., 2014). Using parallel simulations with and without LULC changes, Smith et al. (2016) showed that detectable temperature changes due to LULC could have occurred as early as 7000 years ago (7 ka BP) in summer and throughout the year by $3 \mathrm{ka} \mathrm{BP}$. All of these conclusions, however, are obviously contingent on the imposed LULC forcing, which is highly uncertain.

There have been several attempts to map LULC changes through time (e.g. Ramankutty and Foley, 1999; Pongratz et al., 2008; Kaplan et al., 2011; Klein Goldewijk et al., 2011, $2017 \mathrm{a}, \mathrm{b}$ ). All of these reconstructions assume that anthropogenic land use is a function of population density and the suitability of land for crops and/or pasture. Estimates of regional population trends are then used through time in combination with assumptions about per-capita land use and spatial land use allocation schemes to estimate anthropogenic changes in LULC across time and space. However, differences in the underlying assumptions about land use per capita, which are generalized from limited and often sitespecific data, have resulted in large differences in the final reconstructions (Gaillard et al., 2010; Kaplan et al., 2017). Hence, there are still very large uncertainties about the timing and magnitude of LULC changes, both at a global and at a regional scale (Fig. 1).

There is a wealth of archaeological, historical, and palaeovegetation data that could be used to improve the relatively simple rules used to generate global LULC reconstructions. For example, settlement density and numbers of radiocarbondated artefacts can be used to infer population sizes and their temporal dynamics (Rick, 1987; Williams, 2012; Silva and Vander Linden, 2017). Carbonized and waterlogged plant remains and animal bones can be used to infer the occurrence and nature of agriculture at a site, although their presence provides no quantitative information about the area under cultivation (Wright, 2003; Lyman, 2008; Orton et al., 2016). Although the record of LULC is likely to be patchy and incomplete because of preservation and sampling issues, the systematic use of archaeological data is one important way to improve current LULC scenarios.

The Past Global Change (PAGES; http://www. pastglobalchanges.org/, last access: 14 February 2020) LandCover6k Working Group (http://pastglobalchanges. org/ini/wg/landcover6k, last access: 14 February 2020) is currently working to develop a rigorous and robust approach to provide data and data products that can be used to inform 

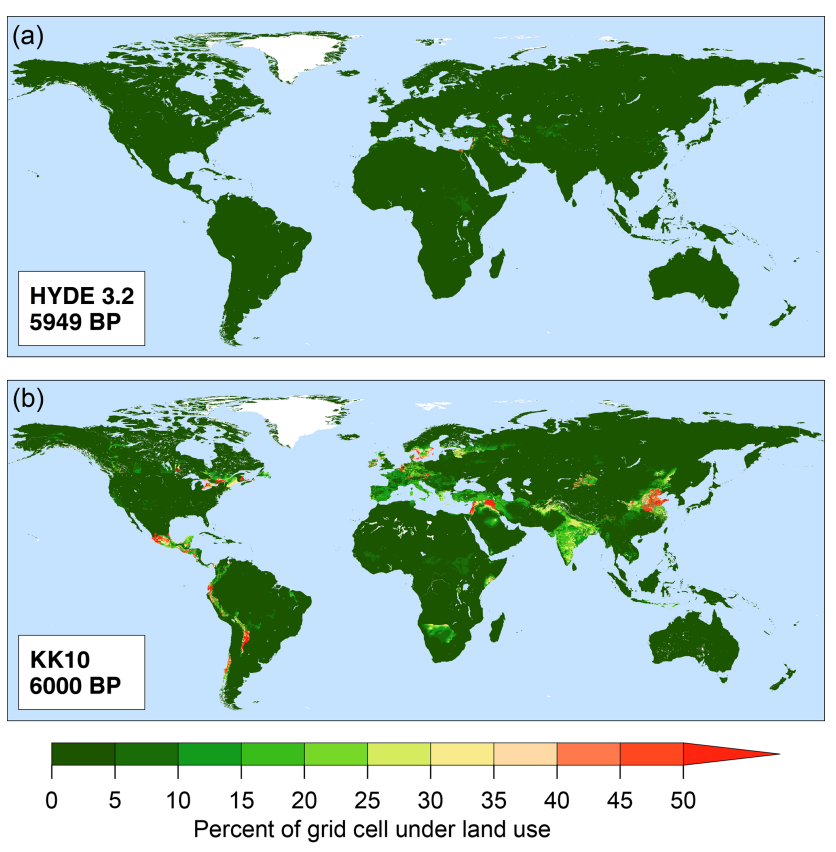

Figure 1. Land use at ca. 6000 years ago (6 ka BP, 4000 years BCE) from the two widely used global historical land use scenarios HYDE 3.2 (a; Klein Goldewijk et al., 2017a) and KK10 (b; Kaplan et al., 2011), illustrating the large disagreement between LULC scenarios at a regional scale. In both scenarios, the land-sea mask and lake areas are for the present day.

the development of LULC scenarios (Gaillard et al., 2018). LULC changes are taken into account in climate model simulations currently being made in the current phase of the Coupled Model Intercomparison Project (CMIP6) for the historic period and the future scenario runs (Eyring et al., 2016). They are also included in climate model simulations of the past millennium (Jungclaus et al., 2017) in order to ensure that these runs mesh seamlessly with the historic simulations. However, the Land Use Harmonization dataset (LUH2: Hurtt et al., 2017) only extends back to $850 \mathrm{CE}$, and thus scenarios of LULC changes are currently not included in the CMIP6 palaeoclimate simulations, including mid-Holocene simulations, that are used as a test of how well state-of-the-art climate models reproduce large climate changes. In this paper, we discuss how archaeological data will be used to improve global LULC scenarios for the Holocene. Given that there are large uncertainties associated with the primary data and further uncertainties may be introduced when this information is used to modify existing LULC scenarios, we outline a series of tests that will be used to evaluate whether the revised LULC scenarios are consistent with the changes implied by independent pollen-based reconstructions of land cover and whether they produce more realistic estimates of both carbon cycle and climate changes. Finally, we present a protocol for implementing LULC in Earth system model simulations to be carried out in the cur- rent phase of the Palaeoclimate Modelling Intercomparison Project (PMIP: Otto-Bleisner et al., 2017; Kageyama et al., 2018). However, the datasets and protocol will also be useful in later phases of other CMIP projects, including the Land Use Model Intercomparison Project (LUMIP) and the Land Surface, Snow and Soil Moisture Model Intercomparison Project (LS3MIP) (Lawrence et al., 2016; van den Hurk et al., 2016).

\section{LandCover6k methodology}

The primary source of information about human exploitation of the landscape comes from archaeological data. In general, these data are site specific, spatiotemporal coverage is often patchy, and the types and quality of evidence available vary between sites and regions. Generalizing from site-specific data to landscape or regional scales involves making assumptions about human behaviour and cultural practices. Because of the inherent uncertainties, we advocate an iterative approach to incorporate archaeological data into LULC scenarios in LandCover6k (Fig. 2). We propose revising the existing LULC scenarios through the incorporation of diverse archaeological inputs (Fig. 2, phase 1; see Sects. 3 and 4) and testing the revised LULC scenarios for their plausibility and consistency with other lines of evidence (Fig. 2, phase 2 with iterative testing; see Sects. 5-7). As a first test, the revised LULC scenarios of the extent of cropland and grazing land through time will be compared with independent data on land cover changes, specifically pollen-based reconstructions of the extent of open land (see e.g. Trondman et al., 2015; Kaplan et al., 2017) (Sect. 5). Further testing the LULC scenarios involves sensitivity tests using global climate models (Sect. 6) and global carbon cycle models (Sect. 7). While the computational cost of the climate model simulations can be minimized using equilibrium time-slice simulations, the carbon cycle constraint relies on transient simulations but may be derived from uncoupled, land-only simulations. Simulated climates at key times can be evaluated against reconstructions of climate variables (e.g. Bartlein et al., 2011) (Sect. 6). The parallel evolution of $\mathrm{CO}_{2}$ and its isotopic composition $\left(\delta^{13} \mathrm{C}\right)$ can be used to derive the carbon balance of the terrestrial biosphere and the ocean separately (Elsig et al., 2009); in combination with estimates for other contributors to land carbon changes such as $\mathrm{C}$ sequestration by peat build-up, it provides a strong constraint on the evolution of LULC through time. An underprediction or overprediction of anthropogenic LULC-related $\mathrm{CO}_{2}$ emissions during a specific interval results in consequences for the dynamics of the atmospheric greenhouse gas burden in subsequent times (Stocker et al., 2017) (Sect. 7). Thus, these tests can be used to identify issues in the original archaeological datasets and/or the way these data were incorporated into the LULC scenarios that require further refinement. Phase 3 of the project (Fig. 2) provides a protocol for the implementa- 


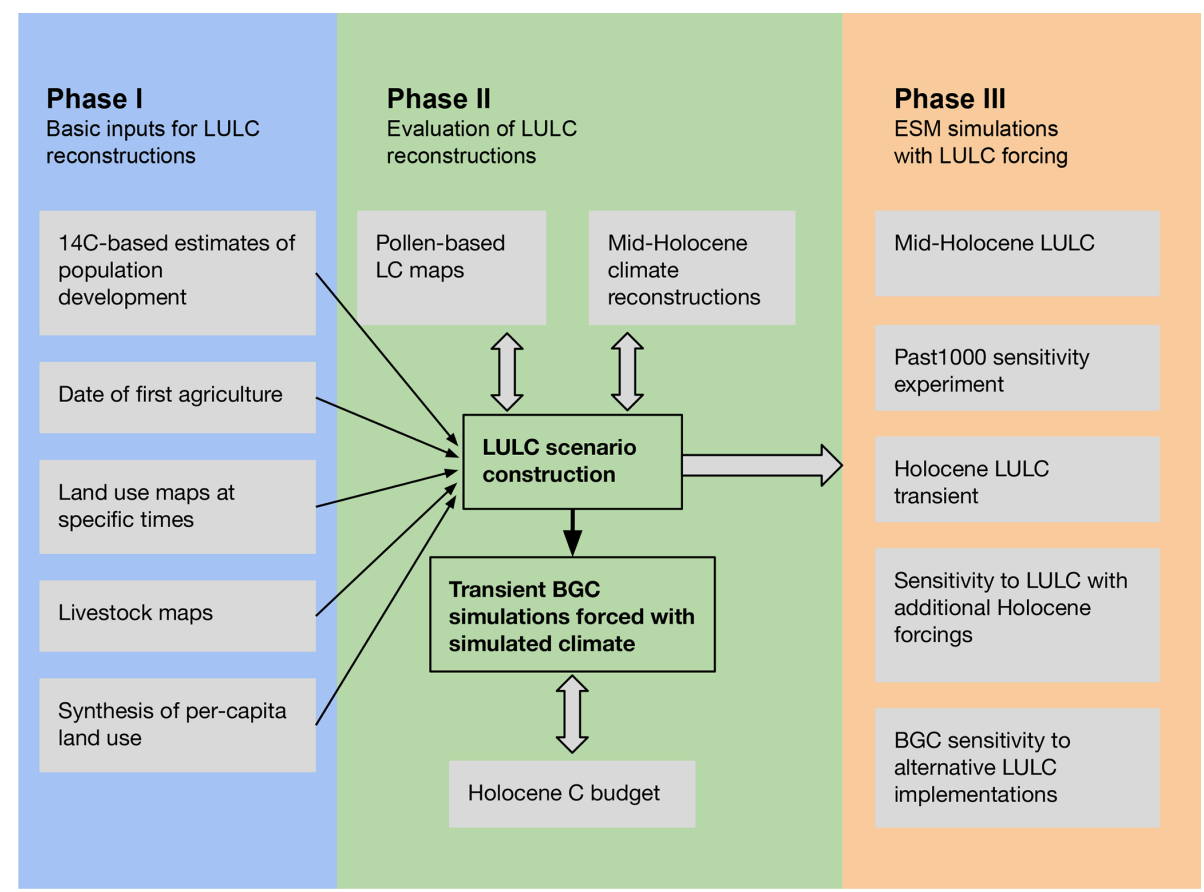

Figure 2. Proposed scheme for developing robust LULC scenarios through iterative testing and refinement as input to Earth system model (ESM) simulations. The archaeological inputs developed in phase 1 can be used independently or together to improve the LULC reconstructions; iterative testing of the LULC scenario reconstruction (phase 2) will ensure that these inputs are reliable before they are used for ESM simulations (phase 3). The uppermost three LULC simulations capitalize on already planned baseline simulations without LULC; the lowermost two simulations are envisaged as new sensitivity experiments.

tion of the revised LULC scenarios in Earth system model simulations (Sect. 8).

\section{Archaeological data inputs}

LandCover6k is creating a number of products that will be used to improve the LULC scenarios (Fig. 2). Here, we summarize the important features of these data products before showing how they will be incorporated within a scenario development framework.

\subsection{Population dynamics from ${ }^{14} \mathrm{C}$ data}

Radiocarbon is the most routinely used absolute dating technique in archaeology, especially for the Holocene. Many thousands of radiocarbon dates are available from the archaeological literature. A number of regional and pan-regional initiatives are compiling these records through exhaustive surveys of the archaeological literature (e.g. the Canadian Archaeological Radiocarbon Database: https://www. canadianarchaeology.ca/, last access: 14 February 2020). Statistical approaches, such as summed probability distributions (SPDs), can then be used to infer past demographic fluctuations from these compilations (Fig. 3). This method assumes that the more people there were, the more remains of their various activities they left behind and that this is di- rectly reflected in the number of samples excavated and dated (Rick, 1987: Robinson et al., 2019). There are biases that could affect the expected one-to-one relationship between the number of people and the number of radiocarbon dates on archaeological material, including lack of uniform sampling through time and space caused by different archaeological research interests and traditions in different regions as well as increased preservation issues with increasing age, but these can be minimized by auditing the datasets. Assessment of the robustness of population reconstructions through time can be made statistically by comparing a null hypothesis of demographic growth constructed from an exponential fit to the data with the actual record of the number of dates through time (Shennan et al., 2013; Timpson et al., 2014). Mathematical simulations show that the method is relatively robust for large sample sizes (Williams, 2012). Radiocarbon dates have been successfully used in several regions to identify population fluctuations associated with hunter-gatherers (Japan: Crema et al., 2016) and the introduction of farming and subsequent changes in farming regimes (western Europe: Shennan et al., 2013; Wyoming: Zahid et al., 2016; South Korea: Oh et al., 2017; see also Freeman et al., 2018) as well as climatic oscillations (Ireland: Whitehouse et al., 2014). 

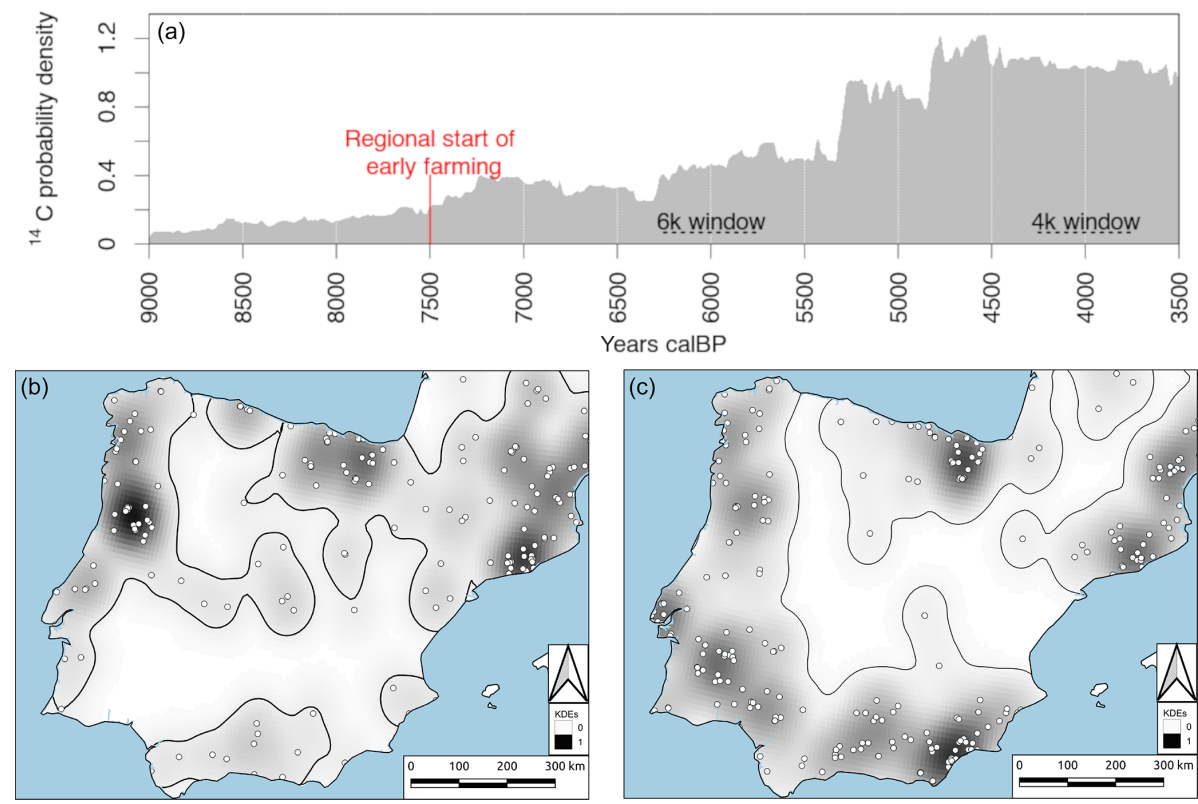

Figure 3. Reconstruction of changes in population size on the Iberian Peninsula during the Holocene ( 9000 to $2000 \mathrm{BP}$, $9 \mathrm{ka}$ to $2 \mathrm{ka}$ BP) using summed probability distributions (SPDs) of radiocarbon dates (a) (data after Balsera et al., 2015). The red line indicates the onset of agriculture in the region. Panels (b) and (c) show areas under human use at $6 \mathrm{ka}$ (b) and $4 \mathrm{ka}$ (c) using kernel density estimates; the white dots are actual archaeological sites, and the shading shows the implied density of occupation.

\subsection{Date of first agriculture}

Radiocarbon dates can also be used to track the timing and process of dispersal events, such as the diffusion of plant and animal domesticates from their initial centres of domestication. Since the distribution of samples is often patchy, geostatistical techniques such as kriging and splines are used to spatially interpolate the information in order to provide quantitative estimates of the timing of spread. Work carried out in Europe (Bocquet-Appel et al., 2009), Asia (Silva et al., 2015), and Africa (Russell et al., 2014) demonstrates that there are different rates of diffusion even within a region, reflecting the possible impact of natural features (e.g. waterways, elevation, ecology) on diffusion rates (Davison et al., 2006; Silva and Steele, 2014). Numerous studies provide robust local estimates for the earliest regional occurrence of agriculture, and these are being synthesized to provide a global product within LandCover6k (Fig. 2).

\subsection{Global land use and livestock maps}

Maps of the distribution of archaeological sites or of areas linked to a given food production system have been produced for individual site catchments or small regions (e.g. Zimmermann et al., 2009; Barton et al., 2010; Kay et al., 2019). LandCover6k is developing global land use maps for specific time windows using a global hierarchical classification of land use categories (Morrison et al., 2018) based on land use types that are widely recognized from the archaeological record. At the highest level, the maps distinguish between areas where there is no (or only limited) evidence of land use and areas characterized by hunting, foraging, and fishing activities, pastoralism, agriculture, and urban and/or extractive land use (Fig. 4). Except in the cases in which land use is minimal (no human land use, extensive or minimal land use), further distinctions are subsequently made to encompass the diversity of land use activities in each land use type (Fig. 4). A third level of distinction is made in the case of two categories (agroforestry, wet cultivation) in which there are very different levels of intervention in different regions. Explanations of this terminology are given in Morrison et al. (2018). The LandCover6k land use maps (see e.g. Fig. 5) will be based on different methods ranging from kernel density estimates to expert assessments depending on the quality and quantity of the archaeological information available from different regions.

There is considerable variation in how intensely land is used both for crops and for grazing within broad land use categories both geographically and through time (Ford and Clarke, 2015; Styring et al., 2017). Maps of land use types do not provide direct information on the intensity of farming practices or how they translate into per-capita land use. Archaeological data about agricultural yields, combined with information from analogous contemporary cultures, historical information (e.g. Pongratz et al., 2008), and theoretical estimates of land use required to meet dietary and energy requirements (e.g. Hughes et al., 2018), can be used to provide regional estimates of per-capita land use for specific land use categories. LandCover6k will synthesize this information to 
Level 1
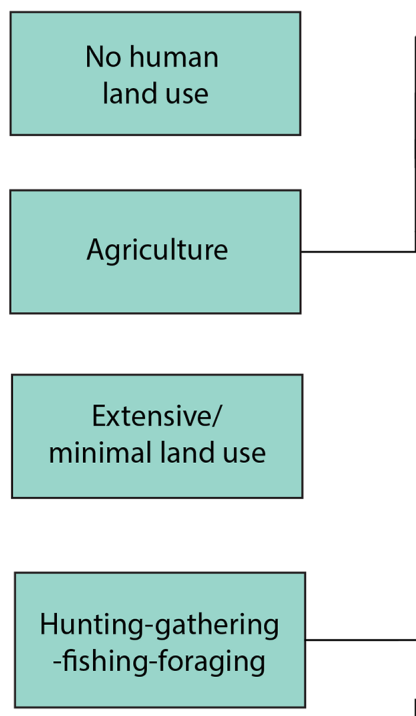

Pastoralism
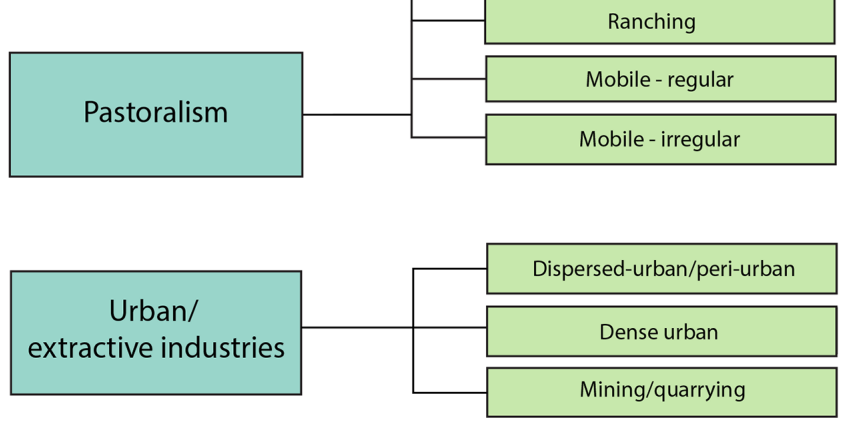

Level 3

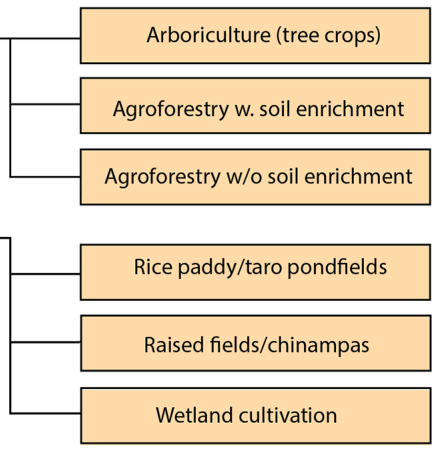

VARIABLES:

CULTIGENS: wheat; barley; pulses; millets; maize; beans; squash; olives; vines; rice (dry/hill); rice (wet/paddy); tubers; teff; orchard/tree crops; sugar cane; oats; rye; sago; cotton; other

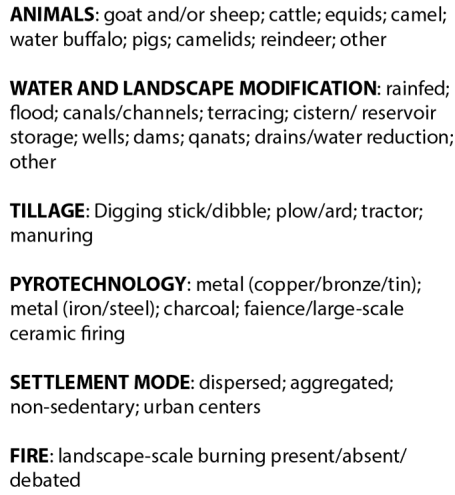

ANIMALS: goat and/or sheep; cattle; equids; came WATER AND LANDSCAPE MODIFICATION: rainfed; flood; canals/channels; terracing; cistern/ reservoir storage; wells; dams; qanats; drains/water reduction;

TILLAGE: Digging stick/dibble; plow/ard; tractor; manuring metal (iron/steel); charcoal; faience/large-scale debated

Figure 4. The hierarchical scheme of land use classes used for global mapping in LandCover6k (updated from Morrison et al., 2018).

allow regionally specific estimates of per-capita land use to be derived from the global land use maps.

Information about the extent of grazing land is an important input for the development of revised LULC scenarios but from a carbon cycle modelling perspective, the amount of biomass removed by grazing is also a key parameter. Biomass loss varies not only with population size but also with the type of animal being reared (Herrero et al., 2013; Phelps and Kaplan, 2017), and thus information about what animals were present at a given location and estimates of population sizes are needed for improving the existing LULC scenarios. Although the conditions of bone preservation vary across the globe due to factors such as soil acidity, animal bones are routinely excavated (Lyman, 2008; Reitz and Wing, 2008). Morphometric analyses of bones, along with collateral information such as age-related culling patterns, make it possible to determine whether these are the remains of domesticated species. We thus have a relatively precise idea of when livestock were introduced into a region, what types of animals were being reared at a given time, and can also make informed estimates of population size. Although the level of detail will vary geographically, this information can be used to produce global livestock maps.

The harvesting of wood for domestic fires, building, and industrial activities such as transportation, pottery making, and metallurgy is an important aspect of human exploitation of the landscape in the pre-industrial period (McGrath et al., 2015). It has been argued that even Mesolithic huntergatherer communities shaped their environment through wood harvesting (Bishop et al., 2015). Approaches have been developed to quantifying the wood harvest associated with archaeological settlements at specific times based on the evidence of types of wood use, household energy requirements, population size, and calorific value of the wood used (see e.g. Marston, 2009; Janssen et al., 2017). However, quantitative information on ancient technology and lifestyle is sparse, and direct estimates of the amount of wood harvest through time are likely to remain highly uncertain (Marston et al., 2017; Veal, 2017). Nevertheless, combining evidence-based inferential approaches with improved estimates of population size should allow changes in wood harvesting to be taken into account in constructing revised LULC scenarios. 

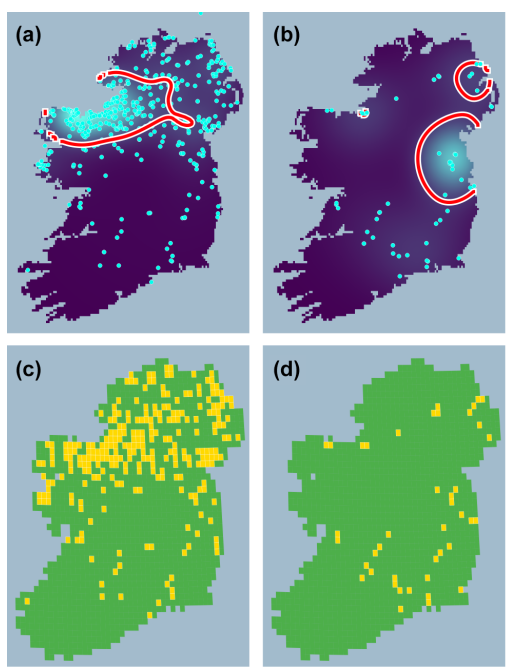

Figure 5. An example of regional land use mapping. (a, b) The distribution of known archaeological sites superimposed on kernel density estimates of the extent of land use based on the density of observations and (c, d) these data superimposed on the LandCover6k land use classes for the middle Neolithic (36003400 years BCE, 5600-5400 years BP, 5.6-5.4 ka BP) (a, c) and the early Neolithic (3750-3600 years BCE, 5750-5600 years BP, 5.7-5.6 ka BP) (b, d) in Ireland. Data points derive from ${ }^{14} \mathrm{C}$-dated archaeological sites and distributions of settlements and monuments that have been assigned to each archaeological period following the dataset published in McLaughlin et al. (2016). The assigned land use classes are inferred from archaeological material from one site (or multiple sites) within the grid box. It should not be assumed that the whole grid cell was being used for agriculture during the middle and early Neolithic. Informed assessment suggests that agricultural land (crop growing and grazing combined) probably occupied $10 \%-15 \%$ of the total grid area in the low-level food production regions of the eastern and western coastal areas, whilst agricultural land likely represents $5 \%$ or less of the total grid cell area in inland areas.

\section{Incorporation of archaeological data in LULC scenarios}

The existing LULC scenarios are substantially dependent on historical regional population estimates at key times, which are then linearly interpolated to provide a year-by-year estimate of population. Estimates of regional population growth based on suitably screened ${ }^{14} \mathrm{C}$ data can be used to modify existing population growth curves (Fig. 6), both in terms of establishing the initial date of human presence and by modifying a linear growth curve to allow for intervals of population growth and decline.

Information on the timing of the first appearance of agriculture at specific locations can be used to constrain the temporal record of LULC changes in the scenarios. This information can also be used to allocate LULC changes geographically across regions (Fig. 6). Global land use maps can be used to identify areas where there was no permanent agricul-

tural activity at a given time (e.g. either unsettled areas or areas occupied by hunter-gatherer communities) and provide a further constraint on the geographic extent of the LULC changes given by the scenarios (Fig. 6). The type of agriculture, including whether the region was predominantly used for tree or annual crops or for pasture, modifies the area of open land specified in the LULC scenarios. Information on the extent of rainfed versus irrigated agriculture, as indicated by the presence of irrigation structures associated with archaeological sites, can also be used to refine the distribution of these classes in the LULC scenarios. Per-capita land use estimates and their changes through time (see e.g. Hughes et al., 2018; Weiberg et al., 2019) provide a further refinement of the LULC scenarios, allowing for a better characterization of the distinction between e.g. areas given over to extensive versus intensive animal production (rangeland versus pasture in the HYDE 3.2 terminology). There will remain areas of the world for which this kind of fine-grained information is not available. Nevertheless, by incorporating information when it exists, the LandCover6k products will contribute to a systematic refinement of existing LULC scenarios. Iterative testing of the revised scenarios will ensure that they are robust.

\section{Using pollen-based reconstructions of land cover changes to evaluate LULC scenarios}

Pollen-based vegetation reconstructions can be used to corroborate archaeological information on the date of first agriculture from the appearance of cereals and agricultural weeds. These reconstructions can also be used to test the LULC reconstructions, either using relative changes in forest cover or reconstructions of the area occupied by different land cover types. LandCover6k uses the REVEALS pollen source-area model (Sugita, 2007) to estimate vegetation cover from fossil pollen assemblages. REVEALS predicts the relationship between pollen deposition in large lakes and the abundance of individual plant taxa in the surrounding vegetation at a large spatial scale (ca. $100 \mathrm{~km} \times 100 \mathrm{~km}$; Hellman et al., 2008a, b) using models of pollen dispersal and deposition. REVEALS can also be used with pollen records from multiple small lakes or peat bogs (Trondman et al., 2016), although this results in larger uncertainties in the estimated area occupied by individual taxa. The estimates obtained for individual taxa are summed to produce estimates of the area occupied by either plant functional (e.g. summergreen trees, evergreen trees) or land cover (e.g. open land, grazing land, cropland) types.

The geographic distribution of pollen records is uneven. There are also many areas of the world where environments that preserve pollen (i.e. lakes, bogs, forest hollows) are sparse. Site-based reconstructions of land cover are therefore interpolated statistically to produce spatially continuous reconstructions (Nielsen et al., 2012; Pirzamanbein et al., 2014, 2018). LandCover6k uses a $1^{\circ}$ resolution grid and all 
Landcover 6K working group

Population, no of $14^{\mathrm{C}}$ date

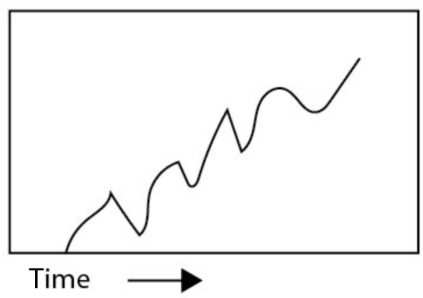

Date of first agriculture

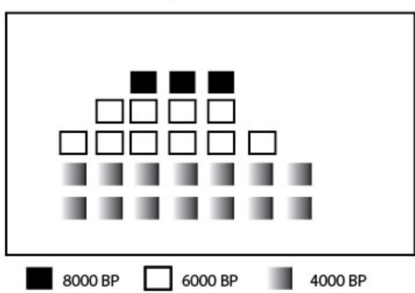

Land use classification input

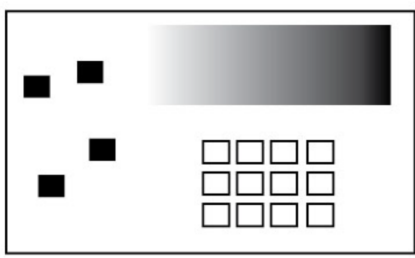

Hunter-gatherer/shifting cultivation

$\square$ Livestock farming

Uninhabited

LU/cap, expert judgment

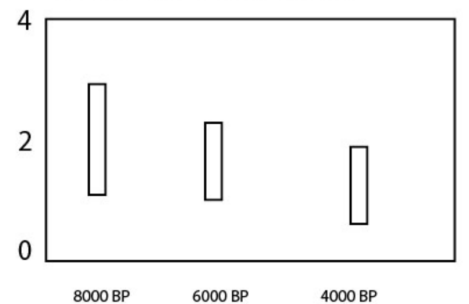

HYDE 3.x

Revised population numbers

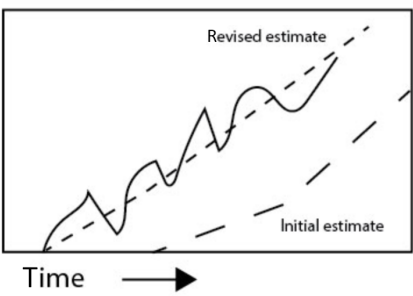

$\%$ agricultural land

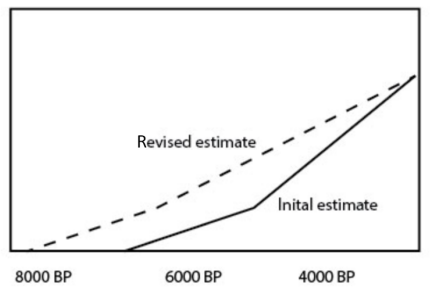

Revised land use allocation

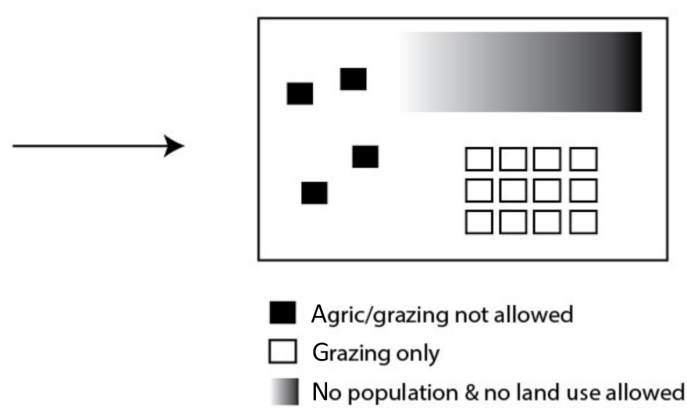

Revised land use per capita

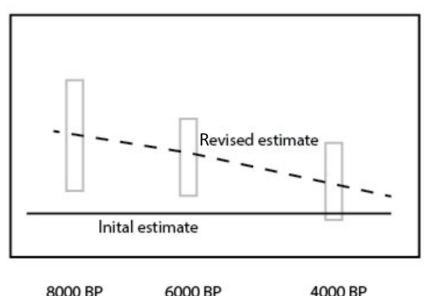

Figure 6. Schematic illustration of the proposed implementation of ${ }^{14} \mathrm{C}$-based population estimates, date of first agriculture, land use maps, and land use per-capita information in the HYDE model (here indicated as HYDE3.x). The archaeological data are represented as values for a grid cell in geographic space at a given time for date of first agriculture and land use, but as a time series for a specific grid cell for population and land use per capita. In the case of population estimates, date of first agriculture, and land use per-capita data, we show the initial estimate and the revised estimate after taking the archaeological information into account in the HYDE3.x plot. It should be assumed in the case of the land use mapping that the original estimate indicated no land use in this region.

available pollen records in each grid cell to produce an estimate of land cover per grid cell through time. The more pollen records per grid cell and pollen counts per time window, the smaller the estimated error on the land cover reconstruction. The uncertainties on the pollen-based REVEALS reconstructions are partly expressed by their standard errors (SEs). These SEs take into account the SE on the relative pollen productivity (RPP) of each plant taxon included in the REVEALS reconstructions and the variability between the site-specific REVEALS reconstructions (e.g. Trondman 

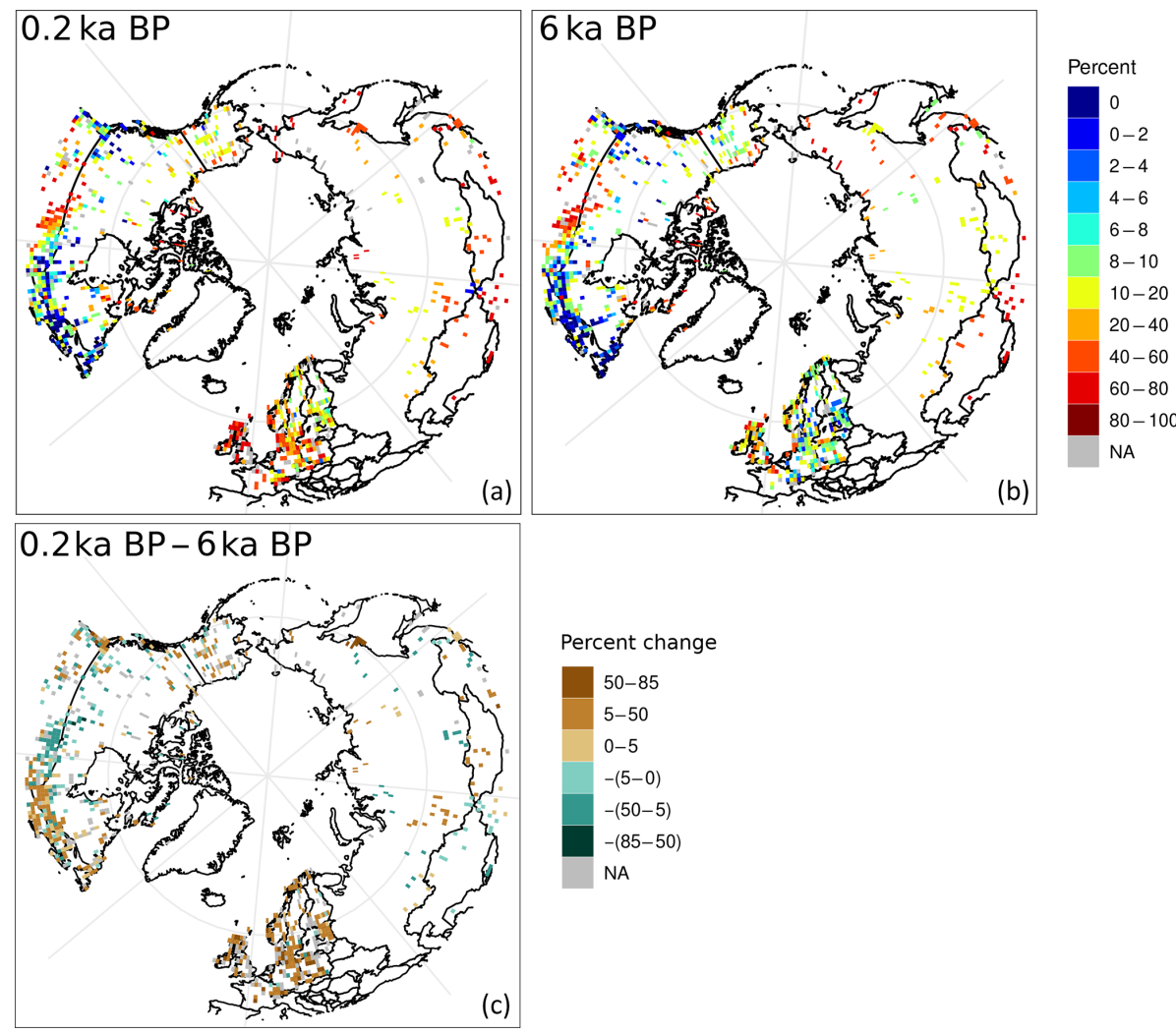

Figure 7. Northern extratropical $\left(>40^{\circ} \mathrm{N}\right)$ mean fractional cover of open land at 6000 years ago (6 ka BP: b) and 200 years ago (0.2 ka BP: a) estimated using REVEALS and the difference in fractional cover between the two periods (c). Red indicates an increase in open land and blue a decrease (after Dawson et al., 2018).

et al., 2015). The uncertainties on the pollen-based land cover reconstructions are taken into account when these reconstructions are compared with LULC scenarios (Kaplan et al., 2017).

The REVEALS approach has already been used to produce gridded reconstructions of changes in the amount of open land through time across the northern extratropics (Fig. 7; Dawson et al., 2018) These reconstructions provide mean plant cover for time slices of 500 years through the Holocene until $0.7 \mathrm{kaBP}$ and three historical time windows (modern - 0.1, 0.1-0.35, and 0.35-0.7 ka BP). The more pollen samples per time interval and pollen records per grid cell, the more years within the 500-year time slice will be represented in the reconstruction. This implies that the number of years represented in a time-slice reconstruction varies in space and time.

A major limitation in applying REVEALS globally is the requirement for information about the relative pollen productivity (RPP) of individual pollen taxa, which is currently largely lacking for the tropics. However, LandCover6k has been collecting RPPs for China, south-east India, Cameroon, Brazil, and Argentina, and pollen-based land cover reconstructions will be available for sufficient parts of the tropics to allow the testing of the LULC scenarios. Another limita- tion of the REVEALS reconstructions is that RPP estimates are available for cultivated cereals but not for other cultivars or cropland weeds, so the LandCover6k pollen-based reconstructions will generally underestimate cropland cover (Trondman et al., 2015). It may also be possible to use alternative pollen-based reconstructions of land cover changes, such as the modern analogue approach (MAT: e.g. Tarasov et al., 2007; Zanon et al., 2018), pseudo-biomization (e.g. Fyfe et al., 2014), or STEPPS (Dawson et al., 2016). While none of these methods require RPPs, MAT and STEPPS can only be applied in regions where the pollen datasets have dense coverage (such as Europe and North America), and pseudobiomization is affected by the non-linearity of the pollenvegetation relationship that the REVEALS approach is designed to remove.

Comparison of the reconstructions of the extent of open land with the LULC deforestation scenarios will provide a first evaluation of the realism of the revised LULC scenarios (e.g. Kaplan et al., 2017). Underestimation or overestimation of open land in the LULC scenarios is not necessarily an indication that these scenarios are inaccurate because (a) pollen-based reconstructions cannot distinguish between anthropogenic and climatically determined natural open land (e.g. natural grasslands, steppes, wetlands), and 

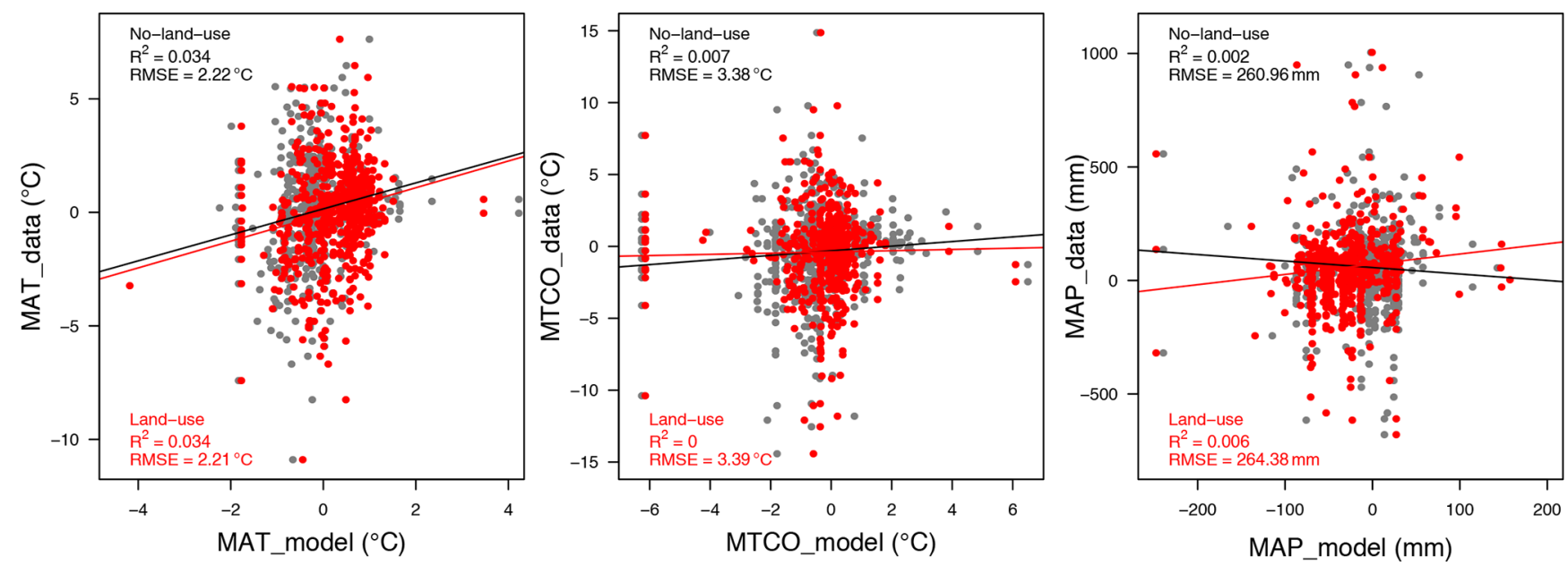

Figure 8. Quantitative comparison of the change in climate between the mid-Holocene $(6 \mathrm{ka})$ and the pre-industrial period as shown by pollen-based reconstructions gridded to $2 \times 2^{\circ}$ resolution to be compatible with the model resolution (from Bartlein et al., 2011) and in simulations with and without the incorporation of land use change (from Smith et al., 2016). This figure illustrates the approach that will be taken to evaluate the impact of new LULC scenarios on climate. The imposed land use changes at 6000 years ago (6 ka BP) were derived from the KK10 scenario (Kaplan et al., 2011). The plots show comparisons of mean annual temperature (MAT), mean temperature of the coldest month (MTCO), and mean annual precipitation (MAP) for the northern extratropics (north of $30^{\circ} \mathrm{N}$ ); each dot represents a model grid cell in which comparisons with the pollen-based reconstructions are possible. Although the incorporation of land use produces somewhat warmer and wetter climates in these simulations, overall the incorporation of land use produces no improvement of the simulated climates at sites with pollen-based reconstructions.

(b) REVEALS underestimates cropland cover because there are no RPP estimates for cultivars other than cereals. However, overestimation of the area of open land in the LULC scenarios might suggest problems either in the archaeological inputs or their implementation, especially for times or regions for which other evidence indicates cereals were the major crop. In this sense, despite potential problems, the LandCover6k pollen-based reconstructions of land cover will provide an important independent test of the revised LULC scenarios.

\section{Testing the reliability of improved scenarios using climate model simulations}

A second test of the realism of the improved LULC scenarios is to examine whether incorporating LULC changes improves the realism of the simulated climate when compared to palaeoclimate reconstructions (Fig. 8). The mid-Holocene (6000 years ago, $6 \mathrm{ka} \mathrm{BP}$ ) is an ideal candidate for such a test because benchmark datasets of quantitative climate reconstructions are available (e.g. Bartlein et al., 2011), the interval has been a focus through multiple phases of PMIP, control simulations with no LULC have already been run, and evaluation of these simulations has identified regions where there are major discrepancies between simulated and reconstructed climates e.g. the observed expansion of Northern Hemisphere monsoons, climate changes over Europe, the magnitude of high-latitude warming, and wetter conditions in central Eurasia (Mauri et al., 2014; Harrison et al., 2015; Bartlein et al., 2017). There are discernible anthropogenic impacts on the landscape in many of these regions by $6 \mathrm{ka}$, although they are not as strong as during the later Holocene and they are not present everywhere. Nevertheless, the $6 \mathrm{kaBP}$ interval provides a good focus for testing whether improvements to the LULC scenarios produces more realistic simulations of climate. Such an evaluation would need to go beyond the global comparison made here (Fig. 8) to regional comparisons to identify whether improvements in simulated climate in regions where there is a large anthropogenic impact on land cover result in a degradation in the simulated climate elsewhere.

\section{Testing the reliability of improved scenarios using carbon cycle models}

Carbon cycle modelling will be used as a further test of the realism of the improved LULC scenarios. Two constraints are available for testing the realism of past LULC scenarios. First, reconstructions of LULC history must converge on the present-day state, which is relatively well constrained by satellite land cover observations and national statistics on the amount of land under use. Reconstructing the extent of past LULC change thus reduces to allocating a fixed total amount of land conversion from natural to agricultural use over time. More conversion in earlier periods implies less conversion in later periods. At the continental to global scale, cumu- 
lative LULC emissions scale linearly with the agricultural area. LULC scenarios that converge to the present-day state also converge to within a small range of cumulative historical emissions (Stocker et al., 2011, 2017). Deviations from a linear relationship between extent and emissions are due to differences in biomass density in potential natural and agricultural vegetation of different regions affected by anthropogenic LULC. Differences in cumulative emissions for alternative LULC reconstructions with an identical present-day state are due to the long response time of soil carbon content following a change in carbon inputs and soil cultivation. Conserving the total extent of LULC (and allocating a fixed total expansion over time) is thus approximately equivalent to conserving cumulative historical LULC emissions. Thus, more LULC $\mathrm{CO}_{2}$ emissions in earlier periods imply less $\mathrm{CO}_{2}$ emissions in more recent periods.

The total $\mathrm{C}$ budget of the terrestrial biosphere provides a second constraint on LULC emissions through time. The net $\mathrm{C}$ balance of the land biosphere, which reflects the sum of all natural and anthropogenic effects on terrestrial $\mathrm{C}$ storage, can be reconstructed from ice core data of past $\mathrm{CO}_{2}$ concentrations and $\delta^{13} \mathrm{C}$ composition (Elsig et al., 2009). Provided that all of the natural contributions to the land $\mathrm{C}$ inventory (e.g. the build-up of natural peatlands: Loisel et al., 2014) can be specified from independent evidence, the anthropogenic sources can be estimated as the difference between the total terrestrial $\mathrm{C}$ budget and natural contributions (Fig. 9) at any specific time.

Transient simulations with a model that simulates $\mathrm{CO}_{2}$ emissions in response to anthropogenic LULC can be used to test the reliability of the LULC scenarios by comparing results obtained with prescribed LULC changes through time against a baseline simulation without imposed LULC. This will necessitate making informed decisions about the fraction of land under cultivation that is abandoned or left fallow each year and the maximum extent of land affected by such episodic cultivation. We envisage using several different offline carbon cycle models for this purpose in order to take account of uncertainties associated with differences between the carbon cycle models. The carbon cycle simulations will be driven by climate outputs (temperature, precipitation, and cloud cover) from an existing transient climate simulation made with the ECHAM model (Fischer and Jungclaus, 2011) and $\mathrm{CO}_{2}$ prescribed from ice core records. The $\mathrm{CO}_{2}$ emission estimates from these two simulations will then be evaluated using $\mathrm{C}$ budget constraints. This evaluation will allow us to pinpoint potential discrepancies between known terrestrial $\mathrm{C}$ balance changes and estimated LULC $\mathrm{CO}_{2}$ emissions in given periods over the Holocene.

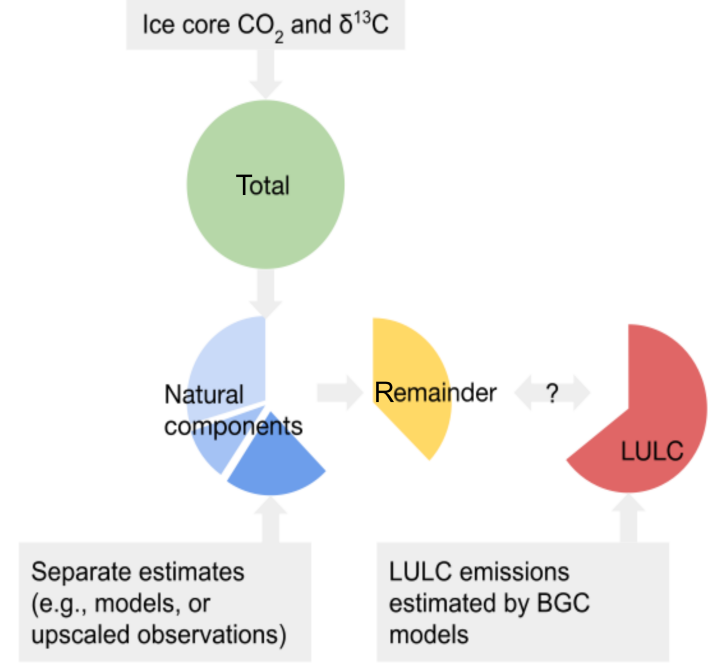

Figure 9. Illustration of the terrestrial $\mathrm{C}$ budget approach to evaluate LULC. The total terrestrial C balance (green circle, "total") is constrained by ice core records of $\mathrm{CO}_{2}$ and its isotopic signature $\left(\delta^{13} \mathrm{C}\right)$. Estimates for $\mathrm{C}$ balance changes in different natural land carbon cycle components (e.g. peatlands, permafrost, forest expansion or retreat, desert greening) are estimated independently (blue slices, "natural components") either from empirical upscaling of site-scale observations or from model-based analyses (carbon cycle models forced with varying climate). The remainder (yellow slice, "remainder") is then calculated as the total terrestrial C balance (green circle, "total") minus the sum of the separate estimates of the natural components (blue slices, "natural components"). The remainder is effectively the emissions resulting from LULC changes and can therefore be compared to $\mathrm{LULC} \mathrm{CO}_{2}$ emission estimates by carbon cycle models.

\section{Implementation of LULC in Earth system model simulations}

We propose a series of simulations to examine the impact of LULC using the revised LULC scenarios from LandCover6k and building on climate model experiments that are currently being run either in CMIP6-PMIP4 (midHolocene, past1000) or within PMIP although not formally included as CMIP6PMIP4 experiments.

The midHolocene (and its corresponding piControl) simulation is one of the PMIP entry cards in the CMIP6-PMIP4 experiments (Kageyama et al., 2018; Otto-Bliesner et al., 2017), and it is therefore logical to propose this period for LULC simulations. The LULC sensitivity experiment (midHoloceneLULC) should therefore follow the CMIP6PMIP4 protocol; that is, it should be run with the same climate model components and following the same protocols for implementing external forcings as used in the two CMIP6-PMIP4 experiments (Table 1). Thus, if the piControl and midHolocene simulations are run with interactive (dynamic) vegetation, then the midHoloceneLULC experiment should also be run with dynamic vegetation in regions where 
Table 1. Boundary conditions for CMIP6-PMIP4 and the mid-Holocene LULC experiments. The boundary conditions for the CMIP6-PMIP4 piControl and midHolocene are described in Otto-Bleisner et al. (2017) and are given here for completeness.

\begin{tabular}{|c|c|c|c|c|}
\hline \multicolumn{2}{|c|}{ Boundary conditions } & \multirow{2}{*}{ 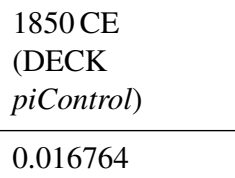 } & $\begin{array}{l}6 \mathrm{ka} \\
\text { (midHolocene) }\end{array}$ & \multirow{2}{*}{$\begin{array}{l}6 \mathrm{ka} \text { LULC } \\
\text { (midHoloceneLULC) }\end{array}$} \\
\hline Orbital & Eccentricity & & 0.018682 & \\
\hline parameters & Obliquity & 23.459 & 24.105 & 24.105 \\
\hline & Perihelion - 180 & 100.33 & 0.87 & 0.87 \\
\hline & Vernal equinox & Noon, 21 March & Noon, 21 March & Noon, 21 March \\
\hline \multirow{4}{*}{$\begin{array}{l}\text { Greenhouse } \\
\text { gases }\end{array}$} & Carbon dioxide (ppm) & 284.3 & 264.4 & 264.4 \\
\hline & Methane (ppb) & 808.2 & 597.0 & 597.0 \\
\hline & Nitrous oxide (ppb) & 273.0 & 262.0 & 262.0 \\
\hline & Other GHGs & DECK piControl & 0 & 0 \\
\hline \multirow{7}{*}{$\begin{array}{l}\text { Other } \\
\text { boundary } \\
\text { conditions }\end{array}$} & Solar constant & TSI: 1360.747 & As piControl & As piControl \\
\hline & Palaeogeography & Modern & As piControl & As piControl \\
\hline & Ice sheets & Modern & As piControl & As piControl \\
\hline & Vegetation & Interactive & Interactive & $\begin{array}{l}\text { Pasture and crop; } \\
\text { distribution prescribed } \\
\text { from a revised scenario }\end{array}$ \\
\hline & & DECK piControl & As piControl & $\begin{array}{l}\text { Pasture and crop; } \\
\text { distribution prescribed } \\
\text { from a revised scenario }\end{array}$ \\
\hline & Aerosols & interactive & Interactive & Interactive \\
\hline & & DECK piControl & As piControl & As piControl \\
\hline
\end{tabular}

there is no LULC change. For most models, this means that the LULC forcing is imposed as a fraction of the grid cell and the remaining fraction of the grid cell has simulated natural vegetation. These new mid-Holocene simulations would allow for a better understanding of the relationship between climate changes and land-surface feedbacks (including snow albedo feedbacks), as well as the role of water recycling at a regional scale. Thus, modelling groups who are running the midHolocene experiment with a fully interactive carbon cycle could also run the LULC experiment allowing atmospheric $\mathrm{CO}_{2}$ to evolve interactively, subject to the simulated ocean and land $\mathrm{C}$ balance.

The real strength of the revised LULC scenarios is to provide boundary conditions for transient climate model simulations. The CMIP6-PMIP4 simulation of 850-1850 CE (past 1000) already incorporates LULC changes as a forcing (Jungclaus et al., 2017) based on a harmonized dataset that provides LULC changes from 850 through $2015 \mathrm{CE}$ (Hurtt et al., 2017), which in turn draws on output from the HYDE3.2 scenario (Klein Goldewijk et al., 2017a). The past1000 protocol (Jungclaus et al., 2017) acknowledges that this default land use dataset is at the lower end of the spread in estimates of early agricultural area indicated by other LULC scenarios and recommends that modelling groups run additional sensitivity experiments using alternative maximum and minimum scenarios. The revised LULC scenarios created by LandCover6k could be used as an alternative to these maximum and minimum scenarios. Other than the substitution of the LandCover6k scenario, the specifications of other forcings would then follow the recommendations for the CMIP6PMIP4 past 1000 simulation.

A transient climate simulation for a longer period of the Holocene would provide a more stringent test of the impact of LULC on the coupled Earth system. We suggest that this transient simulation (holotrans) should start from the preexisting midHolocene simulation to capitalize on the fact that the midHolocene simulation has been spun up sufficiently long (Otto-Bleisner et al., 2017) to ensure that the ocean and land carbon cycle is in equilibrium at the start of the transient experiment (Table 2). In order to be consistent with the CMIP6-PMIP4 midHolocene protocol (Otto-Bleisner et al., 2017), changes in orbital forcing should be specified from Berger and Loutre (1991), and year-by-year changes in $\mathrm{CO}_{2}, \mathrm{CH}_{4}$, and $\mathrm{N}_{2} \mathrm{O}$ should be specified following Joos and Spahni (2008). LULC changes should be implemented by imposing crop and pasture area through time as specified in the revised LULC scenarios; elsewhere, the simulated vegetation should be active. It will be necessary to run the Holocene transient climate simulation in two steps. A first simulation (holotrans_LULC) should be run using prescribed atmospheric $\mathrm{CO}_{2}$ concentration, even though the carbon cycle is fully interactive, because this will establish the consistency of the carbon cycle in the land surface model. However, once this is done it will be possible to rerun the simulations with interactive $\mathrm{CO}_{2}$ emissions. Table 3 provides a summary of the proposed ESM simulations. 
Table 2. Boundary conditions for baseline PMIP Holocene transient (6 ka BP to $1850 \mathrm{CE}$ ) and LULC transient simulations.

\begin{tabular}{|c|c|c|c|c|}
\hline & & Mode & Source or value & LULC experiment \\
\hline Orbital parameters & & Transient & & As baseline simulation \\
\hline Greenhouse gases & $\begin{array}{l}\mathrm{CO}_{2} \\
\mathrm{CH}_{4} \\
\mathrm{~N}_{2} \mathrm{O}\end{array}$ & Transient & $\begin{array}{l}\text { Dome } \mathrm{C} \\
\text { Combined EPICA \& GISP record } \\
\text { Combined EPICA NGRIP, \& TALDICE record }\end{array}$ & $\begin{array}{l}\text { As baseline simulation } \\
\text { As baseline simulation } \\
\text { As baseline simulation }\end{array}$ \\
\hline Solar forcing & & Transient & Steinhilber et al. (2012) & As baseline simulation \\
\hline Volcanic forcing & & Transient & To be determined & As baseline simulation \\
\hline Palaeogeography & & Constant at PI values & Modern & As baseline simulation \\
\hline Ice sheets & & Constant at PI values & Modern & As baseline simulation \\
\hline Vegetation & & Interactive & & $\begin{array}{l}\text { LC6k transient pasture and } \\
\text { crop distribution imposed }\end{array}$ \\
\hline Aerosols & & Constant at PI values & & As baseline simulation \\
\hline
\end{tabular}

Table 3. Summary of proposed simulations.

\begin{tabular}{lll}
\hline Name & Mode & Purpose \\
\hline piControl & Equilibrium & Standard CMIP6-PMIP4 simulation \\
\hline midHolocene & Equilibrium & Standard CMIP6-PMIP4 simulation \\
\hline midHoloceneLULC & Equilibrium & Sensitivity to LULC changes \\
\hline holotrans & Transient & $\begin{array}{l}\text { Baseline fully transient simulation from } \\
\text { 6 ka onwards, with no LULC }\end{array}$ \\
\hline holotrans_LULC & Transient & $\begin{array}{l}\text { Fully transient simulation from 6 ka } \\
\text { onwards, with LULC imposed }\end{array}$ \\
\hline
\end{tabular}

Unlike the situation for the mid-Holocene, wherein there is a global climate benchmark dataset (Bartlein et al., 2011) which provides reconstructions of multiple bioclimatic variables of seasonal temperature and moisture, the opportunities for quantitative evaluation of the holotrans simulated climate are more limited. Seasonal temperature reconstructions are available for Europe (Davis et al., 2003) and North America (Viau et al., 2006; Viau and Gajewski, 2009). Although there is a new global dataset that provides global temperature reconstructions for the Holocene (Kaufman et al., 2020), it is based on only 472 terrestrial records worldwide, and the results for zonally averaged temperature changes are therefore likely to be more robust than the regional details. There are also time series reconstructions for individual sites outside these two regions (e.g. Nakagawa et al., 2002; Wilmshurst et al., 2007; Ortega-Rosas et al., 2008). Furthermore, the simulated time course of $\mathrm{CO}_{2}$ emissions can be compared to the ice core records.

The CMIP6-PMIP4 midHolocene simulations are stylized experiments lacking several potential forcings (in addition to LULC), including changes in atmospheric dust loading, solar irradiance, and volcanic forcing. We suggest that additional sensitivity tests could be run to take these additional forcings into account. In the case of solar and volcanic forcing, this would also ensure that the transient holotrans simulations mesh seamlessly with the past1000 simulation. Changes in solar variability during the Holocene should be specified from Steinhilber et al. (2012). There are records of volcanic forcing for the past 2000 years (Sigl et al., 2015; Toohey and Sigl, 2017), and these are used in the past1000 simulation. Observationally constrained estimates of volcanic stratospheric aerosol for the Holocene are currently under development (Michael Sigl, personal communication, 2019) and could be implemented as an additional sensitivity experiment when available. Changes in atmospheric dust loading are not included in the past 1000 simulation but are important during the earlier part of the Holocene (Pausata et al., 2016; Tierney et al., 2017; Messori et al., 2019). Although continuous reconstructions of dust loading through the Holocene are not available, it would be possible to use estimates for particular time slices (Egerer et al., 2018) to test the sensitivity to this forcing. 


\section{Outcomes and perspectives}

LandCover6k has developed a scheme for using archaeological information to improve existing scenarios of LULC changes during the Holocene, specifically by using archaeological data to provide better estimates of regional population changes through time, better information on the date of the initiation of agriculture in a region, more regionally specific information about the type of land use, and more nuanced information about land use per capita than currently implemented in the LULC scenarios generated by HYDE and KK10. While the final global datasets are still in production, fast-track priority products have been created and their impact on current scenarios is being tested.

Although the work of LandCover6k will provide more solid knowledge about anthropogenic modification of the landscape, some information will inevitably be missing and some key regions will be poorly covered. There will still be large uncertainties associated with revised LULC scenarios, even though these will be based on more solid evidence than the existing LULC scenarios. Documenting the uncertainties in the archaeological inputs and their impacts on the revised scenarios is an important goal of the LandCover6k project. We propose using the information about the uncertainties in the archaeological data sources to generate multiple LULC scenarios comparable to the "low-end" and "high-end" scenarios used for e.g. future projections. Furthermore, we have proposed a series of tests that will help to evaluate the realism of the final scenarios based on independent evidence from pollen-based reconstructions of land cover, reconstructions of climate, and carbon cycle constraints. These tests should help in identifying which of the potential LULC reconstructions are most realistic and in constraining the sources of uncertainty.

We have proposed the use of offline carbon cycle simulations solely as a test of the realism of the revised LULC scenarios. Quantifying the LULC contribution to $\mathrm{CO}_{2}$ emissions during the Holocene would require additional simulations in which other forcings (climate, atmospheric $\mathrm{CO}_{2}$, insolation) are kept constant. The difference in simulated total terrestrial $\mathrm{C}$ storage between these simulations and LULC simulations provides an estimate of primary emissions (Pongratz et al., 2014) and avoids additional model uncertainty regarding the sensitivity of land $\mathrm{C}$ storage to atmospheric $\mathrm{CO}_{2}$ or climate being included in emission estimates. There are other sensitivity tests that would be useful. For example, vegetation-carbon cycle models differ in their ability to account for gross land use transitions within grid cells (Arneth et al., 2017). This is critical for simulating the effects of non-permanent agriculture, whereby land is simultaneously abandoned and reclaimed within the extent of a model grid cell. Such shifting cultivation-type agriculture implies forest degradation in areas recovering from previous land use and leads to substantially higher LULC emissions compared to model estimates wherein only net land use changes are accounted for (Shevliakova et al., 2009). It would therefore be interesting to run additional simulations accounting for net land use change and indeed separating out the effects of wood harvesting and shifting cultivation.

We anticipate that it will be possible to incorporate realistic LULC scenarios for the mid-Holocene as part of the climate model sensitivity experiments planned during PMIP4. Such experiments will complement the CMIP6PMIP4 baseline model experiments by providing insights into whether discrepancies between simulated and observed $6 \mathrm{ka}$ climate could be the result of incorrect specification of the land-surface boundary conditions. However, the incorporation of archaeological information into LULC scenarios clearly makes it possible to target other interesting periods for such experiments, for example to explore whether land use changes played a role in abrupt events such as the $4.2 \mathrm{ka}$ event, the impact of population declines in the Americas as a consequence of European colonization (1500-1750 CE), or the changes in land use globally during the industrial era (post-1850 CE).

In addition to providing a protocol for the PMIP $6 \mathrm{ka}$ sensitivity experiments, we have devised a protocol for implementing the optimal LULC reconstructions for the Holocene in transient climate model or ESM experiments. The goal here is to provide one of the necessary forcings that could be used for transient simulations in future phases of PMIP. This will allow for an assessment of LULC in these simulations and therefore help address issues that are a focus for other MIPs e.g. LUMIP or LS3MIP. When these new forcings are created, they will be made available through the PMIP4 website (https://pmip4.1sce.ipsl.fr/doku.php/exp_design:lgm, last access: 14 February 2020, PMIP4 repository, 2017) and the Earth System Grid Federation (ESGF) Input4MIPS repository (https://esgf-node.llnl.gov/projects/input4mips/, last access: 14 February 2020, with details provided in the "input4MIPs summary" link). Modelling groups who run either equilibrium or transient climate model experiments following this protocol are encouraged to follow the standard CMIP protocol for archiving their simulations through the ESGF.

Code and data availability. The data used for Fig. 1 are publicly available. The HYDE3.2 data can be downloaded from: https://doi.org/10.17026/dans-25g-gez3 (Klein Goldewijk, 2017). The KK10 data can be downloaded from: https://doi.org/10.1594/PANGAEA.871369 (Kaplan and Krumhardt, 2011). The code and data used to generate Fig. 1 are available from: https://github.com/jedokaplan/ALCC_comparison_ figure (Kaplan, 2020). The data and code used to generate Fig. 3 are available from: https://github.com/mavdlind/GMD (Vander Linden, 2020). The data and code used to generate Fig. 5 are available from: https://doi.org/10.5281/zenodo.3625226 (Lewin and Whitehouse, 2020. The European pollen-based reconstructions used in Fig. 7 are available at: https://doi.org/10.1594/PANGAEA.897303 (Gaillard, 2019). The pollen data used to generate the Siberian reconstructions are available from: https://doi.org/10.1594/PANGAEA.898616. 
An earlier version of this figure was published in Dawson et al. (2018). The code used to generate Fig. 7 is available from: https://doi.org/10.5281/zenodo.3604328 (Dawson, 2019). The pollen-based reconstructions used in the generation of Fig. 8 are available from: https://doi.org/10.5281/zenodo.3601028 (Harrison, 2020a). The climate model outputs used to generate Fig. 8 are available from: https://doi.org/10.5281/zenodo.3601040 (Harrison, $2020 \mathrm{~b})$. The code used to generate Fig. 8 is available from: https://doi.org/10.5281/zenodo.3601011 (Harrison, 2020c).

Author contributions. SPH, MJG, BDS, MVL, and KKG wrote the first draft. SPH, PB, and FSRP contributed to the design of the climate model experiments; BS and TK contributed to the design of the carbon cycle simulations. The figures were contributed by JK (Fig. 1), BS (Figs. 2 and 9), MVL (Fig. 3), OB (Fig. 4), NJW (Fig. 5), KKG (Fig. 6), AD (Fig. 7), and SPH (Fig. 8). All authors contributed to the final version of the paper.

Competing interests. The authors declare that they have no conflict of interest.

Special issue statement. This article is part of the special issue " $\mathrm{Pa}$ leoclimate Modelling Intercomparison Project phase 4 (PMIP4) (CP/GMD inter-journal SI)". It is not associated with a conference.

Acknowledgements. LandCover6k is a working group of the Past Global Changes (PAGES) programme, which in turn received support from the Swiss Academy of Sciences. We thank PAGES for their support for this activity. The land use group also received funding under the Holocene Global Landuse International Focus Group of INQUA. SPH acknowledges funding from the European Research Council for "GC2.0: Unlocking the past for a clearer future". Marie-José Gaillard thanks the Swedish Strategic Research Area MERGE (Modelling the Regional and Global Earth System) and Linnaeus University's faculty of Health and Life Sciences (Kalmar, Sweden) for financial support. We thank Joy Singarayer for providing the climate model outputs that were used to generate Fig. 8 and Guangqi Li for assistance in producing this figure. BDS was funded by ERC H2020-MSCA-IF-2015. The dataset for Fig. 5 was generated from the "Cultivating Societies: Assessing the Evidence for Agriculture in Neolithic Ireland" project, supported by the Heritage Council, Ireland, under the INSTAR programme 2008-2010.

Financial support. This research has been supported by the European Research Council (grant nos. 694481 and 701329) and the Heritage Council, Ireland (grant no. 16682).

Review statement. This paper was edited by Richard Neale and reviewed by two anonymous referees.

\section{References}

Arneth, A., Sitch, S., Pongratz, J., Stocker, B. D., Ciais, P., Poulter, B., Bayer, A. D., Bondeau, A., Calle, L., Chini, L. P., Gasser, T., Fader, M., Friedlingstein, P., Kato, E., Li, W., Lindeskog, M., Nabel, J. E. M. S., Pugh, T. A. M., Robertson, E., Viovy, N., Yue, C., and Zaehle, S.: Historical carbon dioxide emissions caused by land-use changes are possibly larger than assumed, Nat. Geosci., 10, 79-84, https://doi.org/10.1038/ngeo2882, 2017.

Arneth, A., Denton, F., Agus, F., Elbehri, A., Erb, K., Elasha, B. O., Rahimi, M., Rounsevell, M., Spence, A., and Valentini, R.: IPCC Special Report on Climate Change, Desertification, Land Degradation, Sustainable Land Management, Food Security, and Greenhouse gas fluxes in Terrestrial Ecosystems, 2019.

Balsera, V., Díaz-del-Río, P., Gilman, A., Uriarte, A., and Vicent, J. M.: Approaching the demography of late prehistoric Iberia through summed calibrated probability distributions (7000-2000 cal BC), Quatern. Int., 208-211, https://doi.org/10.1016/j.quaint.2015.06.022, 2015.

Bartlein, P. J., Harrison, S. P., Brewer, S., Connor, S., Davis, B. A. S., Gajewski, K., Guiot, J., Harrison-Prentice, T. I., Henderson, A., Peyron, O., Prentice, I. C., Scholze, M., Seppä, H., Shuman, B., Sugita, S., Thompson, R. S., Viau, A., Williams, J., and $\mathrm{Wu}, \mathrm{H}$.: Pollen-based continental climate reconstructions at 6 and $21 \mathrm{ka}$ : a global synthesis, Clim. Dynam., 37, 775-802, https://doi.org/10.1007/s00382-010-0904-1, 2011.

Bartlein, P. J., Harrison, S. P., and Izumi, K.: Underlying causes of Eurasian mid-continental aridity in simulations of mid-Holocene climate, Geophys. Res. Lett., 44, 9020-9028, https://doi.org/10.1002/2017GL074476, 2017.

Barton, C. M., Ullah, I. I., and Bergin, S.: Land use, water and Mediterranean landscapes: modelling long-term dynamics of complex socio-ecological systems, Philos. T. Roy. Soc. A,368, 5275-5297, https://doi.org/10.1098/rsta.2010.0193, 2010.

Berger, A. and Loutre, M.-F.: Insolation values for the climate of the last 10 million of years, Quaternary Sci. Rev., 10, 297-317, https://doi.org/10.1016/0277-3791(91)90033-Q, 1991.

Bishop, R. R., Church, M. J., and Rowley-Conwy, P. A.: Firewood, food and human niche construction: the potential role of Mesolithic hunter-gatherers in actively structuring Scotland's woodlands, Quaternary Sci. Rev., 108, 51-75, 2015.

Bocquet-Appel, J.-P., Naji, S., Vander Linden, M., and Kozłowsi, J. $\mathrm{K}$.: Detection of diffusion and contact zones of early farming in Europe from the space-time distribution of ${ }^{14} \mathrm{C}$ dates, J. Arch. Sci., 36, 807-820, https://doi.org/10.1016/j.jas.2008.11.004, 2009.

Crema, E. R., Habu, J., Kobayashi, K., and Madella, M.: Summed probability distribution of ${ }^{14} \mathrm{C}$ dates suggests regional divergences in the population dynamics of the Jomon period in eastern Japan, PlosOne, 11, e0154809, https://doi.org/10.1371/journal.pone.0154809, 2016.

Davis, B. A. S., Brewer, S., Stevenson, A. C., Guiot, J., and Juggins, S.: The temperature of Europe during the Holocene reconstructed from pollen data, Quaternary Sci. Rev., 22, 1701-1716, 2003.

Davison, K., Dolukhanov, P., Sarson, G. R., and Shukurov, P.: The role of waterways in the spread of the Neolithic, J. Arch. Sci., 33, 641-652, https://doi.org/10.1016/j.jas.2005.09.017, 2006.

Dawson, A.: Code to reproduce Figure 7 from Harrison et al., GMD, https://doi.org/10.5281/zenodo.3604328, 2019. 
Dawson, A., Paciorek, C. J., McLachlan, J. S., Goring, S., Williams, J. W., and Jackson, S. T.: Quantifying pollen-vegetation relationships to reconstruct ancient forests using 19th-century forest composition and pollen data, Quaternary Sci. Rev., 137, 156175, https://doi.org/10.1016/j.quascirev.2016.01.012, 2016.

Dawson, A., Cao, X., Chaput, M., Hopla, E., Li, F., Edwards, M., Fyfe, R., Gajewski, K., Goring, S. J., Herzschuh, U., Mazier, F., Sugita, S., Williams, J. W., Xu, Q., and Gaillard, M.-J.: Finding the magnitude of human induced Northern Hemisphere landcover transformation between 6 and $0.2 \mathrm{ka} \mathrm{BP}$, PAGES Mag., 26, 34-35, https://doi.org/10.22498/pages.26.1.34, 2018.

Egerer, S., Claussen, M., and Reick, C.: Rapid increase in simulated North Atlantic dust deposition due to fast change of northwest African landscape during the Holocene, Clim. Past, 14, 10511066, https://doi.org/10.5194/cp-14-1051-2018, 2018.

Elsig, J., Schmitt, J., Leuenberger, D., Schneider, R., Eyer, M., Leuenberger, M., Joos, F., Fischer, H., and Stocker, T. F.: Stable isotope constraints on Holocene carbon cycle changes from an Antarctic ice core, Nature, 461, 507-510, 2009.

Eyring, V., Bony, S., Meehl, G. A., Senior, C. A., Stevens, B., Stouffer, R. J., and Taylor, K. E.: Overview of the Coupled Model Intercomparison Project Phase 6 (CMIP6) experimental design and organization, Geosci. Model Dev., 9, 1937-1958, https://doi.org/10.5194/gmd-9-1937-2016, 2016.

Fischer, N. and Jungclaus, J. H.: Evolution of the seasonal temperature cycle in a transient Holocene simulation: orbital forcing and sea-ice, Clim. Past, 7, 1139-1148, https://doi.org/10.5194/cp-71139-2011, 2011.

Ford, A. and Clarke, K. C.: Linking the past and present of the ancient Maya: lowland land use, population distribution, and density in the Late Classic Period, in: The Oxford Handbook of Historical Ecology and Applied Archaeology, edited by: Isendahl, C. and Stump, D., Oxford University Press, Oxford, https://doi.org/10.1093/oxfordhb/9780199672691.013.33, 2015.

Freeman, J., Baggio, J. A., Robinson, E., Byers, D. A., Gayo, E., Finley, J. B., Meyer, J. A., Kelly, R. L., and Anderies, J. M.: Synchronisation of energy consumption by human societies throughout the Holocene, P. Natl. Acad. Sci. USA, 115, 9962-9967, https://doi.org/10.1073/pnas.1802859115, 2018.

Fyfe, R. M., Woodbridge, J. E., and Roberts, N.: From forest to farmland: pollen-inferred land cover change across Europe using the pseudobiomization approach, Global Change Biol., 21: 1197-1212, https://doi.org/10.1111/gcb.12776, 2014.

Gaillard, M.-J.: First pollen-based REVEALS reconstruction of vegetation abundance in Europe for five time windows between $6 \mathrm{k}$ years $\mathrm{BP}$ and present, PANGAEA, https://doi.org/10.1594/PANGAEA.897303, 2019.

Gaillard, M.-J., Sugita, S., Mazier, F., Kaplan, J. O., Trondman, A.K., Brostroem, A., Hickler, T., Kjellstroem, E., Kunes, P., Lemmen, C., Olofsson, J., Smith, B., and Strandberg, G.: Holocene land-cover reconstructions for studies on land-cover feedbacks, Clim. Past, 6, 483-499, https://doi.org/10.5194/cp-6-483-2010, 2010.

Gaillard, M-J., Whitehouse, N., Madella, M., Morrison, K., and von Gunten, L.: Past land use and land cover, PAGES Mag.,26, 1-44, https://doi.org/10.22498/pages.26.1, 2018.

Harrison, S. P.: Pollen-based reconstructions of bioclimatic variables at $6000 \mathrm{yr} \mathrm{BP}$, https://doi.org/10.5281/zenodo.3601028, 2020a.
Harrison, S. P.: Climate simulations of impact of LULC on mid-Holocene climate, https://doi.org/10.5281/zenodo.3601040, 2020 b.

Harrison, S. P.: Code to compare model outputs and pollen-based reconstructions, https://doi.org/10.5281/zenodo.3601011, 2020c.

Harrison, S. P., Bartlein, P. J., Izumi, K., Li, G., Annan, J., Hargreaves, J., Braconnot, P. B., and Kageyama, M.: Evaluation of CMIP5 palaeo-simulations to improve climate projections, Nat. Clim. Change, 5, 735-743, 2015.

He, F., Vavrus, S. J., Kutzbach, J. E., Ruddiman, W. F., Kaplan, J. O., and Krumhardt, K. M.: Simulating global and local surface temperature changes due to Holocene anthropogenic land cover change, Geophys. Res. Lett., 41, 623-631, 2014.

Hellman, S., Gaillard, M.-J., Broström, A., and Sugita, S.: The REVEALS model, new tool to estimate past regional plant abundance from pollen data in large lakes: validation in southern Sweden, J. Quatenary Sci., 22, 1-22, 2008a.

Hellman, S., Gaillard, M.-J., Broström, A., and Sugita, S.: Effects of the sampling design and selection of parameter values on pollenbased quantitative reconstructions of regional vegetation: a case study in southern Sweden using the REVEALS model, Veg. Hist. Archaeobot., 17, 445-460, 2008b.

Herrero, M., Havlík, P., Valin, H., Notenbaert, A., Rufino, M. C., Thornton, P. K., Blümmel, M., Weiss, F., Grace, D., and Obersteiner, M.: Biomass use, production, feed efficiencies, and greenhouse gas emissions from global livestock systems, P. Natl. Acad. Sci. USA, 110, 20888-20893, 2013.

Hughes, R. E., Weiberg, E., Bonnier, A., Finne, M., and Kaplan, J. O.: Quantifying land use in past societies from cultural practice and archaeological data, Land, 7, 9, https://doi.org/10.3390/land7010009, 2018.

Hurtt, G., Chini, L., Sahajpal, R., Frolking, S., Bodirsky, B. L., Calvin, K., Doelman, J., Fisk, J., Fujimori, S., Klein Goldewijk, K., Hasegawa, T., Havlik, P., Heinimann, A., Humpenöder, F., Jungclaus, J., Kaplan, J., Krisztin, T., Lawrence, D., Lawrence, P., Mertz, O., Pongratz, J., Popp, A., Riahi, K., Shevliakova, E., Stehfest, E., Thornton, P., van Vuuren, D., and Zhang, X.: Harmonization of global land use scenarios (LUH2): SSP585 v2.1f 2015-2100, Earth System Grid Federation, https://doi.org/10.22033/ESGF/input4MIPs.1662, 2017

Janssen, E., Poblome, J., Claeys, J., Kint, V., Degryse, P., Marinova, E., and Muys, B.: Fuel for debating ancient economies. Calculating wood consumption at urban scale in Roman Imperial times, J. Arch. Sci.: Rep., 11, 592-599, 2017.

Joos, F. and Spahni, R.: Rates of change in natural and anthropogenic radiative forcing over the past 20,000 years, P. Natl. Acad. Sci. USA, 105, 1425-1430, 2008.

Joos, F., Gerber, S., Prentice, I. C., Otto-Bliesner, B. L., and Valdes, P. J.: Transient simulations of Holocene atmospheric carbon dioxide and terrestrial carbon since the last glacial maximum, Global Biogeochem. Cy., 18, GB2002, https://doi.org/10.1029/2003GB002156, 2004.

Jungclaus, J. H., Bard, E., Baroni, M., Braconnot, P., Cao, J., Chini, L. P., Egorova, T., Evans, M., González-Rouco, J. F., Goosse, H., Hurtt, G. C., Joos, F., Kaplan, J. O., Khodri, M., Klein Goldewijk, K., Krivova, N., LeGrande, A. N., Lorenz, S. J., Luterbacher, J., Man, W., Maycock, A. C., Meinshausen, M., Moberg, A., Muscheler, R., Nehrbass-Ahles, C., Otto-Bliesner, B. I., Phipps, S. J., Pongratz, J., Rozanov, E., Schmidt, G. A., Schmidt, H., 
Schmutz, W., Schurer, A., Shapiro, A. I., Sigl, M., Smerdon, J. E., Solanki, S. K., Timmreck, C., Toohey, M., Usoskin, I. G., Wagner, S., Wu, C.-J., Yeo, K. L., Zanchettin, D., Zhang, Q., and Zorita, E.: The PMIP4 contribution to CMIP6 - Part 3: The last millennium, scientific objective, and experimental design for the PMIP4 past1000 simulations, Geosci. Model Dev., 10, 40054033, https://doi.org/10.5194/gmd-10-4005-2017, 2017.

Kageyama, M., Braconnot, P., Harrison, S. P., Haywood, A., Jungclaus, J., Otto-Bliesner, B., Peterschmitt, J.-Y., Abe-Ouchi, A., Albani, S., Bartlein, P., Brierley, C., Crucifix, M., Dolan, A., Fernandez-Donado, L., Fischer, H., Hopcroft, P., Ivanovic, R., Lambert, F., Lunt, D., Mahowald, N., Peltier, W. R., Phipps, S., Roche, D., Schmidt, G., Tarasov, L., Valdes, P., Zhang, Q., and Zhou, T.: The PMIP4 contribution to CMIP6 - Part 1: Overview and over-arching analysis plan, Geosci. Model Dev., 11, 10331057, https://doi.org/10.5194/gmd-11-1033-2018, 2018.

Kaplan, J. O.: ALCC_Comparison_Figure, available at: https: //github.com/jedokaplan/ALCC_comparison_figure, last access: 14 February 2020.

Kaplan, J. O. and Krumhardt, K. M.: The KK10 Anthropogenic Land Cover Change scenario for the preindustrial Holocene, PANGAEA, https://doi.org/10.1594/PANGAEA.871369, 2011.

Kaplan, J. O., Krumhardt, K. M., Ellis, E. C., Ruddiman, W. F., Lemmen, C., and Klein Goldewijk, K.: Holocene carbon emissions as a result of anthropogenic land cover change, Holocene, 21, 775-791, 2011.

Kaplan, J. O., Krumhardt, K. M., Gaillard, M.-J., Sugita, S., Trondman, A.-K., Fyfe, R., Marquer, L., Mazier, F., and Nielsen, A. B.: Constraining the deforestation history of Europe: Evaluation of historical land use scenarios with pollen-based land cover reconstructions, Land, 6, 9, https://doi.org/10.3390/land6040091, 2017.

Kaufman, D., McKay, N., Routson, C., Erb, M., Davis, B., Heiri, O., Jaccard, S., Tierney, J., Dätwyler, C., et al.: A global database of Holocene paleo-temperature records, Scient. Data, in press, 2020.

Kay, A. U., Fuller, D. Q., Neumann, K., Eichhorn, B., Höhn, A., Morin-Rivat, J., Champion, L., Linseele, V., Huysecom, E., Ozainne, S., Lespez, L., Biagetti, S., Madella, M., Salzmann, U., and Kaplan, J. O.: Diversification, intensification, and specialization: Changing land use in western Africa from $1800 \mathrm{BC}$ to AD 1500, J. World Prehist., 32, 179-228, https://doi.org/10.1007/s10963-019-09131-2, 2019.

Klein Goldewijk, C. G. M.: Anthropogenic land-use estimates for the Holocene; HYDE 3.2. DANS, https://doi.org/10.17026/dans25g-gez3, 2017.

Klein Goldewijk, K., Beusen, A., van Drecht, G., and de Vos, M.: The HYDE 3.1 spatially explicit database of human induced land use change over the past 12,000 years, Global Ecol. Biogeogr., 20, 73-86, 2011.

Klein Goldewijk, K., Beusen, A., Doelman, J., and Stehfest, E.: Anthropogenic land-use estimates for the Holocene; HYDE 3.2, Earth Syst. Sci. Data, 9, 927-953, https://doi.org/10.5194/essd9-927-2017, 2017a.

Klein Goldewijk, K., Dekker, S. C., and van Zanden, J. L.: Percapita estimations of long-term historical land use and the consequences for global change research, J. Land Use Sci., 12, 313337, https://doi.org/10.1080/1747423X.2017.1354938, 2017 b.
Lawrence, D. M., Hurtt, G. C., Arneth, A., Brovkin, V., Calvin, K. V., Jones, A. D., Jones, C. D., Lawrence, P. J., de NobletDucoudré, N., Pongratz, J., Seneviratne, S. I., and Shevliakova, E.: The Land Use Model Intercomparison Project (LUMIP) contribution to CMIP6: rationale and experimental design, Geosci. Model Dev., 9, 2973-2998, https://doi.org/10.5194/gmd-9-29732016, 2016.

Le Quéré, C., Andrew, R. M., Friedlingstein, P., Sitch, S., Hauck, J., Pongratz, J., Pickers, P. A., Korsbakken, J. I., Peters, G. P., Canadell, J. G., Arneth, A., Arora, V. K., Barbero, L., Bastos, A., Bopp, L., Chevallier, F., Chini, L. P., Ciais, P., Doney, S. C., Gkritzalis, T., Goll, D. S., Harris, I., Haverd, V., Hoffman, F. M., Hoppema, M., Houghton, R. A., Hurtt, G., Ilyina, T., Jain, A. K., Johannessen, T., Jones, C. D., Kato, E., Keeling, R. F., Goldewijk, K. K., Landschützer, P., Lefèvre, N., Lienert, S., Liu, Z., Lombardozzi, D., Metzl, N., Munro, D .R., Nabel, J. E. M. S., Nakaoka, S.-I., Neill, C., Olsen, A., Ono, T., Patra, P., Peregon, A., Peters, W., Peylin, P., Pfeil, B., Pierrot, D., Poulter, B., Rehder, G., Resplandy, L., Robertson, E., Rocher, M., Rödenbeck, C., Schuster, U., Schwinger, J., Séférian, R., Skjelvan, I., Steinhoff, T., Sutton, A., Tans, P. P., Tian, H., Tilbrook, B., Tubiello, F. N., van der Laan-Luijkx, I. T., van der Werf, G. R., Viovy, N., Walker, A. P., Wiltshire, A. J., Wright, R., Zaehle, S., and Zheng, B.: Global Carbon Budget 2018, Earth Syst. Sci. Data, 10, 21412194, https://doi.org/10.5194/essd-10-2141-2018, 2018.

Lewin, S. and Whitehouse, N.: Regional Land Use mapping code and dataset for Early and Middle Neolithic Ireland (3750-3600 cal BC and 3600-3400 cal BC, respectively), https://doi.org/10.5281/zenodo.3625226, 2020.

Loisel, J., Yu, Z., Beilman, D. W., Camill, P., Alm, J., Amesbury, M. J., Anderson, D., Andersson, S., Bochicchio, C., Barber, K., Belyea, L. R., Bunbury, J., Chambers, F. M., Charman, D. J., Vleeschouwer, F.D., Fiałkiewicz-Kozieł, B., Finkelstein, S. A., Gałka, M., Garneau, M., Hammarlund, D., Hinchcliffe, W., Holmquist, J., Hughes, P., Jones, M. C., Klein, E. S., Kokfelt, U., Korhola, A., Kuhry, P., Lamarre, A., Lamentowicz, M., Large, D., Lavoie, M., MacDonald, G., Magnan, G., Mäkilä, M., Mallon, G., Mathijssen, P., Mauquoy, D., McCarroll, J., Moore, T. R., Nichols, J., O'Reilly, B., Oksanen, P., Packalen, M., Peteet, D., Richard, P. J., Robinson, S., Ronkainen, T., Rundgren, M., Sannel, A. B. K., Tarnocai, C., Thom, T., Tuittila, E.-S., Turetsky, M., Väliranta, M., and der Linden, M., van Geel B., van Bellen, S., Vitt, D., Zhao, Y., and Zhou, W.: A database and synthesis of northern peatland soil properties and Holocene carbon and nitrogen accumulation, Holocene, 24, 1028-1042, 2014.

Lyman, R. L.: Quantitative Paleozoology, Cambridge University Press, Cambridge, 2008.

Maezumi, S. Y., Robinson, M., de Souza, J., Urrego, D. H., Schaan, D., Alves, D., and Iriarte, J.: New insights from pre-Columbian land use and fire management in Amazonian Dark Earth forests, Front. Ecol. Evol., 6, 111, https://doi.org/10.3389/fevo.2018.00111, 2018.

Mahowald, N. M., Randerson, J. T., Lindsay, K., Munoz, E., Doney, S. C., Lawrence, P., Schlunegger, S., Ward, D. S., Lawrence, D. and Hoffman, F. M.: Interactions between land use change and carbon cycle feedbacks, Global Biogeochem. Cy., 31, 96-113, https://doi.org/10.1002/2016GB005374, 2017.

Marston, J. M.: Modeling wood aquisition strategies from archaeological charcoal remains, J. Arch. Sci., 36, 2192-2200, 2009. 
Marston, J. M., Holdaway, S. J., and Wendrich, W.: Early- and middle-Holocene wood exploitation in the Fayum basin, Egypt, Holocene, 27, 1812-1824, 2017.

Mauri, A., Davis, B. A. S., Collins, P. M., and Kaplan, J. O.: The influence of atmospheric circulation on the mid-Holocene climate of Europe: a data-model comparison, Clim. Past, 10, 1925-1938, https://doi.org/10.5194/cp-10-1925-2014, 2014.

Mazoyer, M. and Roudart, L.: A History of World Agriculture: From the Neolithic to the Current Crisis, Earthscan, UK, 2006.

McGrath, M. J., Luyssaert, S., Meyfroidt, P., Kaplan, J. O., Burgi, M., Chen, Y., Erb, K., Gimmi, U., McInerney, D., Naudts, K., Otto, J., Pasztor, F., Ryder, J., Schelhaas, M. J., and Valade, A.: Reconstructing European forest management from 1600 to 2010, Biogeoscience, 12, 4291-4316, https://doi.org/10.5194/bg-124291-2015, 2015.

McLaughlin, T. R., Whitehouse, N. J., Schulting, R. J., McClatchie, M., Barratt, P., and Bogaard, A.: The changing face of Neolithic and Bronze Age Ireland: A big data approach to the settlement and burial records, J. World Prehist., 29, 117-153, https://doi.org/10.1007/s10963-016-9093-0, 2016.

Messori, G., Gaetani, M., Zhang, Q., Zhang, Q., and Pausata, F. S. R.: The water cycle of the mid-Holocene West African monsoon: The role of vegetation and dust emission changes, Int. J. Climatol., 39, 1927-1939, https://doi.org/10.1002/joc.5924, 2019.

Mitchell, L., Brook, E., Lee, J., Buizert, C., and Sowers, T.: Constraints on the late Holocene anthropogenic contribution to the atmospheric methane budget, Science, 342, 964-966, https://doi.org/10.1126/science.1238920, 2013.

Morrison, K. D., Hammer, E., Popova, L., Madella, M., Whitehouse, N., Gaillard, M.-J., and LandCover6k Land-Use Group Members: Global-scale comparisons of human land use: developing shared terminology for land-use practices for global changes, PAGES Mag., 26, 8-9, 2018.

Myhre, G., Shindell, D., Bréon, F.-M., Collins, W., Fuglestvedt, J., Huang, J., Koch, D., Lamarque, J.-F., Lee, D., Mendoza, B., Nakajima, T., Robock, A., Stephens, G., Takemura T., and Zhang, H.: Anthropogenic and natural radiative forcing, in: Climate Change 2013: The Physical Science Basis. Contribution of Working Group I to the Fifth Assessment Report of the Intergovernmental Panel on Climate Change, edited by: Stocker, T. F., Qin, D., Plattner, G.-K., Tignor, M., Allen, S. K., Boschung, J., Nauels, A., Xia, Y., Bex, V., and Midgley, P. M., Cambridge University Press Cambridge, Cambridge, UK and New York, NY, USA, 2013.

Nakagawa, T., Tarasov, P. E., Nishida, K., Gotanda, K., and Yasuda, Y.: Quantitative pollen-based climate reconstruction in central Japan: application to surface and Late Quaternary spectra, Quaternary Sci. Rev., 21, 2099-2113, 2002.

Nielsen, A. B., Giesecke, T., Theuerkauf, M., Feeser, I., Behre, K.-H., Beug, H.-J., Chen, S.-H., Christiansen, J., Dörfler, W., Endtmann, E., Jahns, S., de Klerk, O., Kühl, N., Latałowa, M., Odgaard, B. V., Rasmussen, P., Stockholm, J. R., Voigt, R., Wiethold, J., and Wolters, S.: Quantitative reconstructions of changes in regional openness in north-central Europe reveal new insights into old questions, Quaternary Sci. Rev., 47, 131-149, 2012.

Oh, Y., Conte, M., Kang, S., Kim, J., and Hwang, J.: Population fluctuation and the adoption of food production in prehistoric Korea: using radiocarbon dates as a proxy for population change, Radiocarbon, 59, 1761-1770, https://doi.org/10.1017/RDC.2017.122, 2017.

Ortega-Rosas, C. I., Guiot, J., Penalba, M. C., and Ortiz-Acosta, M. E.: Biomization and quantitative climate reconstruction techniques in northwestern Mexico - with an application to four Holocene pollen sequences, Global Planet. Change, 61, 242-266, 2008.

Orton, D., Gaastra, J., and Vander Linden, M.: Between the Danube and the Deep Blue Sea: zooarchaeological meta-analysis reveals variability in the spread and development of $\mathrm{Ne}$ olithic farming across the western Balkans, Open Quat., 2, 6, https://doi.org/10.5334/oq.28, 2016.

Otto-Bliesner, B. L., Braconnot, P., Harrison, S. P., Lunt, D. J., Abe-Ouchi, A., Albani, S., Bartlein, P. J., Capron, E., Carlson, A. E., Dutton, A., Fischer, H., Goelzer, H., Govin, A., Haywood, A., Joos, F., LeGrande, A. N., Lipscomb, W. H., Lohmann, G., Mahowald, N., Nehrbass-Ahles, C., Pausata, F. S. R., Peterschmitt, J.-Y., Phipps, S. J., Renssen, H., and Zhang, Q.: The PMIP4 contribution to CMIP6 - Part 2: Two interglacials, scientific objective and experimental design for Holocene and Last Interglacial simulations, Geosci. Model Dev., 10, 3979-4003, https://doi.org/10.5194/gmd-10-3979-2017, 2017.

Pausata, F. S. R., Messori, G., and Zhang, Q.: Impacts of dust reduction on the northward expansion of the African monsoon during the Green Sahara period, Earth Planet. Sc. Lett., 434, 298-307, https://doi.org/10.1016/j.epsl.2015.11.049, 2016.

Perugini, L. Caporaso, L., Marconi, S., Cescatti, A., Quesada, B., de Noblet-Ducoudré, N., House, J. I., and Arneth, A.: Biophysical effects on temperature and precipitation due to land cover change, Environ. Res. Lett., 12, 053002 , https://doi.org/10.1088/1748-9326/aa6b3f, 2017.

Phelps, L. N. and Kaplan, J. O.: Land use for animal production in global change studies: Defining and characterizing a framework, Global Change Biol., 23, 4457-4471, https://doi.org/10.1111/gcb.13732, 2017.

Pirzamanbein, B., Lindström, J., Poska, A., Sugita, S., Trondman, A., Fyfe, R., Mazier, F., Nielsen, A. B., Kaplan, J. O., Bjune, A. E., Birks, H. J. B., Giesecke, T., Kangur, M., Latałowa, M., Marquer, L., Smith, B., and Gaillard, M.-J.: Creating spatially continuous maps of past land cover from point estimates: A new statistical approach applied to pollen data, Ecol. Complex., 20, 127-141, 2014.

Pirzamanbein, B., Lindström, J., Poska, A., and Gaillard, M.-J.: Modelling spatial compositional data: Reconstructions of past land cover and uncertainties, Spat. Stat., 24, 14-31, 2018.

Pongratz, J., Reick, C., Raddatz, T., and Claussen, M.: A reconstruction of global agricultural areas and land cover for the last millennium, Global Biogeochem. Cy., 22, GB3018, https://doi.org/10.1029/2007GB003153, 2008.

Pongratz, J., Reick, C. H., Raddatz, T., and Claussen, M.: Biogeophysical versus biogeochemical climate response to historical anthropogenic land cover change, Geophys. Res. Lett., 37, L08702, https://doi.org/10.1029/2010GL043010, 2010.

Pongratz, J., Reick, C. H., Houghton, R. A., and House, J. I.: Terminology as a key uncertainty in net land use and land cover change carbon flux estimates, Earth Syst. Dynam., 5, 177-195, https://doi.org/10.5194/esd-5-177-2014, 2014. 
Ramankutty, N. and Foley, J. A.: Estimating historical changes in global land cover: Croplands from 1700 to 1992, Global Biogeochem. Cy., 13, 997-1027, 1999.

Reitz, E. J. and Wing, E. S.: Zooarchaeology, Cambridge University Press, Cambridge, 2008.

Rick, J. W.: Dates as data: an examination of the Peruvian Preceramic radiocarbon record, Am. Antiq., 52, 55-73, 1987.

Robinson, E., Zahid, H. J., Codding, B. F., Haas, R., and Kelly, R. L.: Spatiotemporal dynamics of prehistoric human population growth: radiocarbon 'dates as data' and population ecology models, J. Arch. Sci., 101, 63-71, 2019.

Ruddiman, W. F.: The anthropogenic greenhouse era began thousands of years ago, Climatic Change, 61, 261-293, https://doi.org/10.1023/B:CLIM.0000004577.17928.fa, 2003.

Russell, T., Silva, F., and Steele, J.: Modelling the spread of farming in the Bantu-speaking regions of Africa: an archaeology-based phylogeography, Plos One, 9, e87584, https://doi.org/10.1371/journal.pone.0087854, 2014.

Shennan, S., Downey, S. S., Timpson, A., Edinborough, K., Colledge, S., Kerig, T., Manning, K., and Thomas, M. G.: Regional population collapse followed initial agriculture booms in mid-Holocene Europe, Nat. Commun., 4, 248, https://doi.org/10.1038/ncomms3486, 2013.

Shevliakova, E., Pacala, S. W., Malyshev, S., Hurtt, G. C., Milly, P. C. D., Caspersen, J. P., Sentman, L. T., Fisk, J. P., Wirth, C., and Crevoisier, C.: Carbon cycling under 300 years of land use change: Importance of the secondary vegetation sink, Global Biogeochem. Cy., 23, GB2022, https://doi.org/10.1029/2007GB003176, 2009.

Sigl, M., Winstrup, M., McConnell, J. R., Welten, K. C., Plunkett, G., Ludlow, F., Büntgen, U., Caffee, M., Chellman, N., Dahl-Jensen, D., Fischer, H., Kipfstuhl, S., Kostick, C., Maselli, O. J., Mekhaldi, F., Mulvaney, R., Muscheler, R., Pasteris, D. R., Pilcher, J. R., Salzer, M., Schüpbach, S., Steffensen, J. P., Vinther, B. M., and Woodruff, T. E.: Timing and climate forcing of volcanic eruptions for the past 2,500 years, Nature, 523, 543-549, https://doi.org/10.1038/nature14565, 2015.

Silva, F. and Steele, J.: New methods for reconstructing geographical effects on dispersal rates from largescale radiocarbon databases, J. Arch. Sci., 52, 609-620, https://doi.org/10.1016/j.jas.2014.04.021, 2014.

Silva, F. and Vander Linden, M.: Amplitude of travelling front as inferred from ${ }^{14} \mathrm{C}$ predicts levels of genetic admixture among European early farmers, Sci. Rep., 7, 11985, https://doi.org/10.1038/s41598-017-12318-2, 2017.

Silva, F., Stevens, C. J., Weisskopf, A., Castillo, C., Qin, L., Bevan, A., and Fuller, D. Q.: Modelling the geographical origin of rice cultivation in Asia using the Rice Archaeological Database, Plos One, 10, e0137024, https://doi.org/10.1371/journal.pone.0137024, 2015.

Singarayer, J. S., Valdes, P. J., Friedlingstein, P., Nelson, S., and Beerling, D. J.: Late Holocene methane rise caused by orbitally controlled increase in tropical sources, Nature, 470, 8285, https://doi.org/10.1038/nature09739, 2011.

Smith, M. C., Singarayer, J. S., Valdes, P. J., Kaplan, J. O., and Branch, N. P.: The biogeophysical climatic impacts of anthropogenic land use change during the Holocene, Clim. Past, 12, 923-941, https://doi.org/10.5194/cp-12-923-2016, 2016.
Steinhilber, F., Abreu, J. A., Beer, J., Brunner, I., Christl, M., Fischer, H., Heikkilä, U., Kubik, P. W., Mann, M., McCracken, K. G., Miller, H., Miyahara, H., Oerter, H., and Wilhelms, F.: 9400 years of cosmic radiation and solar activity from ice cores and tree rings, P. Natl. Acad. Sci. USA, 109, 5967-5971, 2012.

Stocker, B. D., Strassmann, K., and Joos, F.: Sensitivity of Holocene atmospheric $\mathrm{CO}_{2}$ and the modern carbon budget to early human land use: analyses with a process-based model, Biogeosciences, 8, 69-88, https://doi.org/10.5194/bg-8-69-2011, 2011.

Stocker, B. D., Yu, Z., Massa, C., and Joos, F.: Holocene peatland and ice-core data constraints on the timing and magnitude of $\mathrm{CO}_{2}$ emissions from past land use, P. Natl. Acad. Sci. USA, 114, 1492-1497, https://doi.org/10.1073/pnas.1613889114, 2017.

Styring, A., Rösch, M., Stephan, E., Stika, H.-P., Fischer, E., Sillmann, E., and Bogaard, A.: Centralisation and long-term change in farming regimes: comparing agricultural practices in Neolithic and Iron Age south-west Germany, Proc. Prehist. Soc., 83, 357 381, https://doi.org/10.1017/ppr.2017.3, 2017.

Sugita, S.: Theory of quantitative reconstruction of vegetation I: pollen from large sites REVEALS regional vegetation composition, Holocene, 17, 229-241, 2007.

Tarasov, P., Williams, J. W., Andreev, A., Nakagawa, T., Bezrukova, E., Herzschuh, U., Igarashi, Y., Müller, S., Werner, K., and Zheng, Z.: Satellite- and pollen-based quantitative woody cover reconstructions for northern Asia: Verification and application to late-Quaternary pollen data, Earth Planet. Sc. Lett., 264, 284 298, 2007.

Tauger, M. B.: Agriculture in World History, Routledge, Oxford, 2013.

Tierney, J. E., Pausata, F. S. R., and deMenocal, P. B.: Rainfall regimes of the Green Sahara, Sci. Adv., 3, e1601503, https://doi.org/10.1126/sciadv.1601503, 2017.

Timpson, A., Colledge, S., Crema, E., Edinborough, K., Kerig, T., Manning, K., Thomas, M. G., and Shennan, S.: Reconstructing regional population fluctuations in the European Neolithic using radiocarbon dates: a new case-study using an improved method, J. Arch. Sci., 52, 549-557, https://doi.org/10.1016/j.jas.2014.08.011, 2014.

Toohey, M. and Sigl, M.: Volcanic stratospheric sulphur injections and aerosol optical depth from 500 BCE to 1900 CE, Earth Syst. Sci. Data, 9, 809-831, https://doi.org/10.5194/essd-9-809-2017, 2017.

Trondman, A. K., Gaillard, M.-J., Mazier, F., Sugita, S., Fyfe, R., Nielsen, A. B., Twiddle, C., Barratt, P., Birks, H. J. B., Bjune, A. E., Björkman, L., Broström, A., Caseldine, C., David, R., Dodson, J., Dörfler, W., Fischer, E., van Geel, B., Giesecke, T., Hultberg, T., Kalnina, L., Kangur, M., van der Knaap, P., Koff, T., Kuneš, P., Lagerås, P., Latałowa, M., Lechterbeck, J., Leroyer, C., Leydet, M., Lindbladh, M., Marquer, L., Mitchell, F. J. G., Odgaard, B. V., Peglar, S. M., Persson, T., Poska, A., Rösch, M., Seppä, H., Veski, S., and Wick, L.: Pollen-based quantitative reconstructions of Holocene regional vegetation cover (plant-functional types and land-cover types) in Europe suitable for climate modelling, Global Change Biol., 21, 676-697, https://doi.org/10.1111/gcb.12737, 2015.

Trondman, A.-K., Gaillard, M.-J., Sugita, S., Björkman, L., Greisman, A., Hultberg, T., Lagerås, P., and Lindbladh, M.: Are pollen records from small sites appropriate for REVEALS model-based quantitative reconstructions of past regional vegetation? An em- 
pirical test in southern Sweden, Veget. Hist. Archaeobot., 25, 131-151, https://doi.org/10.1007/s00334-015-0536-9, 2016.

van den Hurk, B., Kim, H., Krinner, G., Seneviratne, S. I., Derksen, C., Oki, T., Douville, H., Colin, J., Ducharne, A., Cheruy, F., Viovy, N., Puma, M. J., Wada, Y., Li, W., Jia, B., Alessandri, A., Lawrence, D. M., Weedon, G. P., Ellis, R., Hagemann, S., Mao, J., Flanner, M. G., Zampieri, M., Materia, S., Law, R. M., and Sheffield, J.: LS3MIP (v1.0) contribution to CMIP6: the Land Surface, Snow and Soil moisture Model Intercomparison Project - aims, setup and expected outcome, Geosci. Model Dev., 9, 2809-2832, https://doi.org/10.5194/gmd-9-2809-2016, 2016.

Vander Linden, M.: Code for fig 3 of https://doi.org/10.5194/gmd2019-125, available at: https://github.com/mavdlind/GMD, last access: 14 February 2020.

Vavrus, S., Ruddiman, W. F., and Kutzbach, J. E.: Climate model tests of the anthropogenic influence on greenhouse-induced climate change: the role of early human agriculture, industrialization, and vegetation feedbacks, Quaternary Sci. Rev., 27, 14101425, 2008.

Veal, R.: Wood and charcoal for Rome: towards an understanding of ancient regional fuel economics, in: Rural communities in a globalizing economy: new perspectives on the economic integration of Roman Italy, edited by: de Haas, T. and Gijs, T., Brill, New York, Leiden, 388-406, 2017.

Viau, A. E. and Gajewski, K.: Reconstructing millennial, regional paleoclimates of boreal Canada during the Holocene, J. Climate, 22, 316-330, 2009.

Viau, A. E., Gajewski, K., Sawada, M., and Fines, P.: Meancontinental July temperature variability in North America during the past 14,000 years, J. Geophys. Res.-Atmos., 111, D09102, https://doi.org/10.1029/2005JD006031, 2006.

Weiberg, E., Hughes, R. E., Finné, M., Bonnier, A., and Kaplan, J. O.: Mediterranean land use systems from prehistory to antiquity: a case study from Peloponnese (Greece), J. Land Use Sci., 14, 1-20, https://doi.org/10.1080/1747423x.2019.1639836, 2019.
Whitehouse, N., Schulting, R. J., McClatchie, M., Barratt, P., LcLaughlin, T. R., Bogaard, A., Colledge, S., Marchant, R., Gaffrey, J., and Bunting, M. J.: Neolithic agriculture on the European western frontier: the boom and bust of early farming in Ireland, J. Arch. Sci., 51, 181-205, https://doi.org/10.1016/j.jas.2013.08.009, 2014.

Williams, A.: The use of summed radiocarbon probability distributions in archaeology: a review of methods, J. Archaeol. Sci., 39, 578-589, https://doi.org/10.1016/j.jas.2011.07.014, 2012.

Wilmshurst, J. M., McGlone, M. S., Leathwick, J. R., and Newnham, R. M.: A pre-deforestation pollen-climate calibration model for New Zealand and quantitative temperature reconstructions for the past 18000 years BP, J. Quaternay Sci., 22, 535-547, 2007.

Wright, P.: Preservation or destruction of plant remains by carbonization, J. Arch. Sci., 30, 577-583, https://doi.org/10.1016/S0305-4403(02)00203-0, 2003.

Zahid, H. J., Robinson, E., and Kelly, R. L.: Agriculture, population growth, and statistical analysis of the radiocarbon record, P. Natl. Acad. Sci. USA, 113, 931-935, https://doi.org/10.1073/pnas.1517650112, 2016.

Zanon, M., Davis, B. A. S., Marquer, L., Brewer, S., and Kaplan, J. O.: European forest cover during the past 12,000 years: a palynological reconstruction based on modern analogs and remote sensing, Front. Plant Sci., 9, 253, https://doi.org/10.3389/fpls.2018.00253, 2018.

Zimmermann, A., Wendt, K. P., and Hilpert, J.: Landscape archaeology in central Europe, Proc. Prehist. Soc., 75, 1-53, https://doi.org/10.1017/S0079497X00000281, 2009.

Zohary, D., Hopf, M., and Weiss, E.: Domestication of Plants in the Old World: The Origin and Spread of Domesticated Plants in South-west Asia, Europe, and the Mediterranean Basin, 4th Edn., Oxford University Press, Oxford, 2012. 